\title{
Microstructure and Interfacial Reactions During Active Metal Brazing of Stainless Steel to Titanium
}

\author{
A. LAIK, A.A. SHIRZADI, R. TEWARI, ANISH KUMAR, T. JAYAKUMAR, \\ and G.K. DEY
}

\begin{abstract}
Microstructural evolution and interfacial reactions during active metal vacuum brazing of $\mathrm{Ti}$ (grade-2) and stainless steel (SS 304L) using a Ag-based alloy containing $\mathrm{Cu}, \mathrm{Ti}$, and $\mathrm{Al}$ was investigated. A Ni-depleted solid solution layer and a discontinuous layer of $(\mathrm{Ni}, \mathrm{Fe})_{2} \mathrm{TiAl}$ intermetallic compound formed on the SS surface and adjacent to the SS-braze alloy interface, respectively. Three parallel contiguous layers of intermetallic compounds, $\mathrm{CuTi}, \mathrm{AgTi}$, and $(\mathrm{Ag}, \mathrm{Cu}) \mathrm{Ti}_{2}$, formed at the Ti-braze alloy interface. The diffusion path for the reaction at this interface was established. Transmission electron microscopy revealed formation of nanocrystals of $\mathrm{Ag}-\mathrm{Cu}$ alloy of size ranging between 20 and $30 \mathrm{~nm}$ in the unreacted braze alloy layer. The interdiffusion zone of $\beta$-Ti( $\mathrm{Ag}, \mathrm{Cu})$ solid solution, formed on the Ti side of the joint, showed eutectoid decomposition to lamellar colonies of $\alpha$-Ti and internally twinned $(\mathrm{Cu}, \mathrm{Ag}) \mathrm{Ti}_{2}$ intermetallic phase, with an orientation relationship between the two. Bend tests indicated that the failure in the joints occurred by formation and propagation of the crack mostly along the Tibraze alloy interface, through the $(\mathrm{Ag}, \mathrm{Cu}) \mathrm{Ti}_{2}$ phase layer.
\end{abstract}

DOI: $10.1007 / \mathrm{s} 11661-012-1599-1$

(C) The Minerals, Metals \& Materials Society and ASM International 2013

\section{INTRODUCTION}

TITANIUM is the material of natural choice in various industrial applications due to its unique combination of specific strength and excellent corrosion resistance. The extensive use of $\mathrm{Ti}$ and its alloys in various sectors, for example, aerospace, transportation, chemical, nuclear, and power generation, requires them to be joinied to other materials for integration and fabrication of various components. ${ }^{[1,2]}$ Of particular interest to the nuclear industry, is the application of $\mathrm{Ti}$ in fabricating the dissolvers of spent nuclear fuel used in reprocessing plants. This requires it to be joined to the piping of the plant, which is generally made of stainless steel (SS).${ }^{[3]}$ However, in spite of such vital applications, success in producing reliable and strong Ti-SS joints has been limited, primarily due to the lack of metallurgical compatibility that leads to the formation of brittle intermetallic compounds between these materials. ${ }^{[4-7]}$

A review of the literature reveals that the existing methods of joining Ti and its alloys to SS include fusion welding, solid-state diffusion bonding, and vacuum

A. LAIK, Scientific Officer (F), R. TEWARI, Scientific Officer (H), and G.K. DEY, Head, are with the Materials Science Division, Bhabha Atomic Research Centre, Mumbai 400085, India. Contact e-mail: laik@barc.gov.in A.A. SHIRZADI, Lecturer, is with the Materials Engineering, The Open University, Milton Keynes MK7 6AA, UK. ANISH KUMAR, Scientific Officer (F), is with the Non Destructive Evaluation Division, Indira Gandhi Centre for Atomic Research, Kalpakkam 603102, Tamil Nadu, India. T. JAYAKUMAR, Director, is with the Metallurgy and Materials Group, Indira Gandhi Centre for Atomic Research.

Manuscript submitted April 17, 2012.

Article published online February 12, 2013 brazing. ${ }^{[8]}$ Conventional fusion welding has not been a good choice since it needs to be performed in inert atmosphere due to the reactive nature of $\mathrm{Ti}$, and the significant difference in physico-chemical properties of the two materials that lead to chemical, mechanical, and structural inhomogeneities. ${ }^{[7]}$ Although the progress of research on diffusion bonding of SS to $\mathrm{Ti}$ with suitable interlayers has led to some success, formation of undesirable intermetallic compounds of various combinations such as $\mathrm{Ti}-\mathrm{Fe}$, Ti-Cr and $\mathrm{Ti}-\mathrm{Ni}$ could not be completely eliminated. ${ }^{[2,9]}$ The formation of these intermetallics produces residual stresses originating from a mismatch in their thermal expansion. ${ }^{[7,10,11]}$ Also, the requirement of the surface preparation stage and impracticality of the method for mass production have limited its use. ${ }^{[8,11-14]}$ Explosion welding has also been used to clad Ti to SS plates in many applications. ${ }^{[8,15-17]}$ However, recent reports on the formation of brittle intermetallics such as $\mathrm{FeTi}$ and $\mathrm{Fe}_{2} \mathrm{Ti}^{[18]}$ and accumulation of considerably high residual stresses $(\sim 1000 \mathrm{MPa})^{[19]}$ at the Ti-SS interface of joints, revealed by X-ray diffraction and neutron diffraction studies, respectively, puts the use of these joints in critical applications into question. Compared to the aforementioned techniques, vacuum brazing offers two major advantages: (1) low thermal residual stresses in the joints, as a major part of the stresses generated due to differential contraction of the two materials, are relieved by plastic deformation of the ductile braze alloys; and (2) a low compressive stress is required for joining. ${ }^{[7]}$

Dececco and Parks ${ }^{[20]}$ suggested the use of silver and its alloys to braze $\mathrm{Ti}$ and since then various silver-based filler alloys have been extensively used for the brazing of $\mathrm{Ti}$ and its alloys, primarily due to good flow characteristics of these filler alloys and high strength and adequate 
ductility of these brazed joints. ${ }^{[21]} \mathrm{Ti}$ is sometimes added in small quantities ( $\sim$ to $4 \mathrm{wt}$ pct) to silver-based brazing alloys to improve wettability with SS. Development of a brazing technique, capable of producing joints with desired properties, would require identifying the chemical reactions undergoing at the interfaces and understanding the mechanisms of these reactions. Previous work on brazing of titanium to steels concentrated mainly on investigating the suitability of the use of various brazing alloys and optimizing the parameters with respect to the mechanical properties. ${ }^{[9,22-29]}$ Microstructural and chemical analyses of the brazing zone at a submicron length scale, using techniques such as transmission electron microscopy (TEM), were not attempted in these studies. The lack of TEM studies may be attributed to the experimental difficulty in specimen preparation due to brittleness of the joints, differential thinning on either side of the joint, and the low success rate of achieving electron transparency in the regions around the joint interface.

Against this background, the present article reports an in-depth investigation on the microstructural evolution and phase relationship in active metal brazing of SS to $\mathrm{Ti}$, using a silver-based alloy containing $\mathrm{Cu}, \mathrm{Al}$, and Ti. The objective of the work was to study the various processes taking place during brazing, including those occurring at the interfaces, that lead to successful joints. The mechanisms of the interfacial relations and the mode of failure of the brazed joints were also identified.

\section{EXPERIMENTAL PROCEDURE}

\section{A. Materials}

The base materials used in the experiments were annealed plates of commercially pure grade-2 titanium (ASTM B265) and austenitic SS (AISI 304L). The nominal compositions of these materials are given in Table I. Rectangular pieces of size $15 \mathrm{~mm} \times 15 \mathrm{~mm} \times 5 \mathrm{~mm}$ were cut from the plates of both materials. The larger faces of the pieces were ground with successive grades of emery papers up to 1200 grit, followed by $1 \mu \mathrm{m}$ diamond polish. A silverbased alloy containing 5 pet $\mathrm{Cu}, 1$ pct $\mathrm{Al}$, and 1.25 pct Ti (wt pct), commercially known as Silver-ABA, ${ }^{*}$ was used

* Silver-ABA is a trademark of Wesgo Metals, a part of The Morgan Crucible Co., plc. Berkshire, United Kingdom.

in the form of $50 \mu \mathrm{m}$ thick foil for brazing. The solidus and liquidus temperatures of the alloy were confirmed to be $1133 \mathrm{~K}$ and $1185 \mathrm{~K}\left(860{ }^{\circ} \mathrm{C}\right.$ and $\left.912{ }^{\circ} \mathrm{C}\right)$, respectively, using a differential thermal analyzer. The surface of the foil was ground using 2400 grit emery paper to remove any surface-oxide layer, and then treated in dilute nitric acid for a short duration. Prior to bonding, all the components were washed and rinsed in ethyl alcohol followed by final cleaning in an ultrasonic bath containing acetone.

\section{B. Brazing Procedure}

Sandwich-type braze joints of the Ti and SS pieces were prepared by aligning them with Silver-ABA alloy foil in between the two base materials. The assembly was placed in a resistance heating vacuum brazing furnace. The pieces were clamped together between the two rams of a hydraulic load transfer mechanism, and a dead load of about $2 \mathrm{~kg}$ was applied to keep them in place. Mica spacers were used on either side of the couple to prevent any possible reaction between the joint assembly and the loading rams. The chamber of the furnace was maintained at about $5 \times 10^{-5}$ mbar vacuum throughout the brazing operation. The heating rate of the furnace was $10 \mathrm{~K} / \mathrm{min}\left(10^{\circ} \mathrm{C} / \mathrm{min}\right)$, and the temperature of the furnace was controlled within $\pm 1 \mathrm{~K}\left(1^{\circ} \mathrm{C}\right)$ using a proportional-integral-derivative controller. The exact temperature of the assembly was monitored using an additional thermocouple with its tip placed very close to the Ti-SS interface. Based on a few preliminary experiments, the peak brazing temperature was selected as $1203 \mathrm{~K}\left(930{ }^{\circ} \mathrm{C}\right)$ [i.e., $18 \mathrm{~K}\left(18{ }^{\circ} \mathrm{C}\right)$ above the liquidus] with a dwell time of 15 minutes, to obtain sufficient wetting of the brazing surfaces and adequate reaction at the interfaces. The brazed couples were finally cooled in the furnace under vacuum. The schedule for the entire brazing operation is represented as a time-temperature plot in Figure 1. The rate of cooling of the couples was initially about $20 \mathrm{~K} / \mathrm{min}\left(20^{\circ} \mathrm{C} / \mathrm{min}\right)$ up to about $973 \mathrm{~K}$ $\left(700{ }^{\circ} \mathrm{C}\right)$ and gradually decreased at lower temperatures to about $5 \mathrm{~K} / \mathrm{min}\left(5^{\circ} \mathrm{C} / \mathrm{min}\right)$.

\section{Characterization of the Brazed Joints}

The soundness of the joint was evaluated by using ultrasonic imaging. $\mathrm{C}$-scan imaging was carried out at $0.50 \mathrm{~mm}$ spacing using a $25 \mathrm{MHz}$ immersion transducer with $35 \mathrm{~mm}$ focal length, from both $\mathrm{Ti}$ and SS sides of the joint. One of the joints was sectioned in the direction perpendicular to the bond interface, using a slow speed diamond blade, and the cross section was prepared for microscopic examination using standard metallographic techniques and was subsequently etched with a solution of 5 pct $\mathrm{HF}, 40$ pct $\mathrm{HNO}_{3}$, and 55 pct $\mathrm{H}_{2} \mathrm{O}$, by volume. The microstructure of the braze zone (BZ) was characterized using an optical microscope, and a scanning electron microscope (SEM). Orientation imaging maps were acquired from a region at the brazed interface

Table I. Chemical Composition of the Base Materials (Weight Percent)

\begin{tabular}{|c|c|c|c|c|c|c|c|c|c|}
\hline Elements & $\mathrm{C}$ & $\mathrm{H}$ & $\mathrm{O}$ & $\mathrm{Mn}$ & $\mathrm{Si}$ & $\mathrm{Ni}$ & $\mathrm{Cr}$ & $\mathrm{Fe}$ & $\mathrm{Ti}$ \\
\hline Ti Gr-2 & 0.009 & 0.008 & 0.12 & - & - & 0.011 & - & 0.09 & bal. \\
\hline SS- 304L & 0.02 & - & - & 1.47 & 0.52 & 10.6 & 19.1 & bal. & - \\
\hline
\end{tabular}




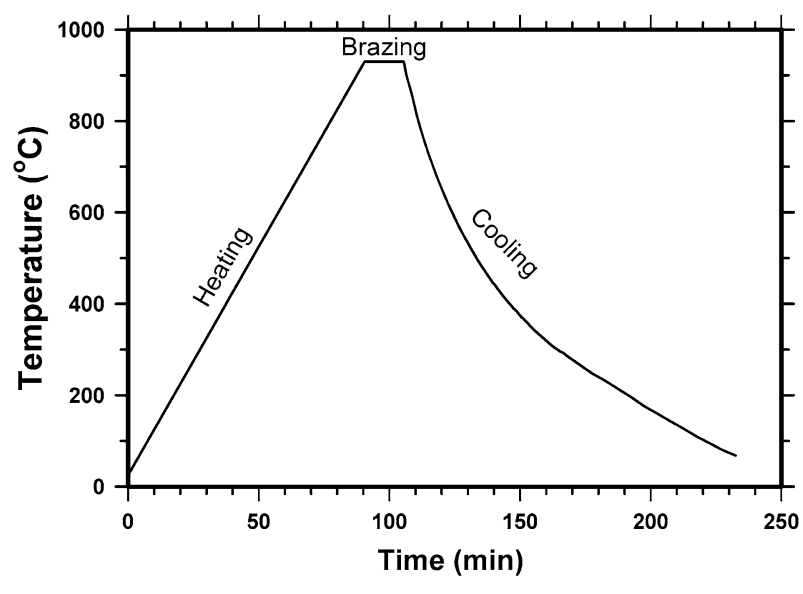

Fig. 1-Time-temperature plot showing the schedule for brazing SS to titanium using Silver-ABA alloy.

using electron backscattered diffraction (EBSD) detectors in the SEM. The finer details of the microstructure were characterized using a Zeiss Ultra 55 Plus** field

**Zeiss Ultra 55 Plus is a trademark of Carl Zeiss AG, Germany.

emission scanning electron microscope (FESEM), and the chemical analysis was carried out using an energy dispersive spectrometer (EDS) attached to it.

Microanalysis of the reaction products formed at the interfaces was carried out using a Cameca SX100

${ }^{\dagger}$ Cameca SX100 is a trademark of CAMECA SAS, France.

electron probe microanalyser (EPMA) equipped with three wavelength dispersive spectrometers (WDSs). X-ray maps of the different elements were acquired to determine the distribution and partitioning of the elements in the BZ. Quantitative analysis was performed on a point-topoint basis to determine the composition of the phases formed. The EPMA was operated at $15 \mathrm{kV}$ acceleration voltage and a $20 \mathrm{nA}$ stable beam current. Pure elemental standards were used for calibration of the spectrometers, and a PAP program ${ }^{[30]}$ was used for matrix correction. The composition of each phase was averaged over the results of at least three different locations. The variation in the microhardness across the brazed cross section was recorded using a microhardness tester.

With the objective to investigate the microstructure at submicron scale, the brazed joints were also characterized using TEM. A rod with diameter $3 \mathrm{~mm}$ was extracted from the SS-Ti brazed interface by electrical discharge machining. Thin slices of thickness 0.2 to $0.3 \mathrm{~mm}$ were cut from the rod using a precision diamond blade. Thin foils for TEM observation were prepared from these slices by mechanical grinding, followed by electropolishing in a solution containing perchloric acid and methanol in the ratio 1:4 and finally ion milling with Ar-ions. The foils were examined in JEOL ${ }^{\star} 2000 \mathrm{FX}$ and

JEOL is a trademark of Japan Electron Optics Ltd., Tokyo.

TITAN-300 transmission electron microscopes.

\section{Bending Test}

Thin slices with thickness in the range 0.3 to $0.5 \mathrm{~mm}$ were cut from a brazed SS-Ti sample using a highprecision disc-cutting machine. Each slice was subjected to bending stress across its bond line until a crack was initiated (Reference 31 provides details). The location and direction of propagation of the cracks were examined using an SEM.

\section{RESULTS}

\section{A. Ultrasonic Evaluation of Joint Interface}

Figure 2 shows the results of the ultrasonic test in A, $\mathrm{B}$, and $\mathrm{C}$ scan modes. Uniform amplitude of the interface and the back-wall echoes at all the locations indicate a good quality of bonding between the $\mathrm{Ti}$ and SS pieces. These test results also showed that small sized defects such as porosity or lack of fusion were not present at the SS-Ti interface.

\section{B. Microstructure of the Braze Zone}

A typical microstructure of the cross section of the BZ of the SS-Ti joint, brazed at $1203 \mathrm{~K}\left(930{ }^{\circ} \mathrm{C}\right)$ for 15 minutes is shown in Figure 3. It was noted that the interfaces between the braze alloy and the base materials, on either side, were free from pores, cracks, or discontinuities.

The entire BZ, as shown in Figure 3, may be divided into four zones, marked as A through $\mathrm{D}$ in the figure. On the SS side, at the interface between SS and braze alloy, a layer A with a uniform thickness of about 5 to $6 \mu \mathrm{m}$ was found to form parallel to the original interface. Layer B, of about $30 \mu \mathrm{m}$ thickness, was the unreacted braze alloy, consisting mainly of $\mathrm{Ag}$ and $\mathrm{Cu}$. Due to solid-liquid interaction on the Ti side of the BZ, parallel layers of intermetallic compounds with planar morphology, collectively marked as zone C in Figure 3, were formed. It was further observed that due to diffusion of some elements from the brazing alloy into $\mathrm{Ti}$, the microstructure of bulk $\mathrm{Ti}$ was modified up to a depth of about $40 \mu \mathrm{m}$ (layer D). X-ray maps of elements $\mathrm{Fe}, \mathrm{Ni}, \mathrm{Cr}, \mathrm{Ag}, \mathrm{Cu}, \mathrm{Al}$, and $\mathrm{Ti}$ along with the corresponding backscattered electron (BSE) image of a typical region of the BZ is shown in Figure 4. The distribution of various elements and their partitioning behavior in the four zones A through $\mathrm{D}$ are depicted clearly in these images. The chemical compositions of 

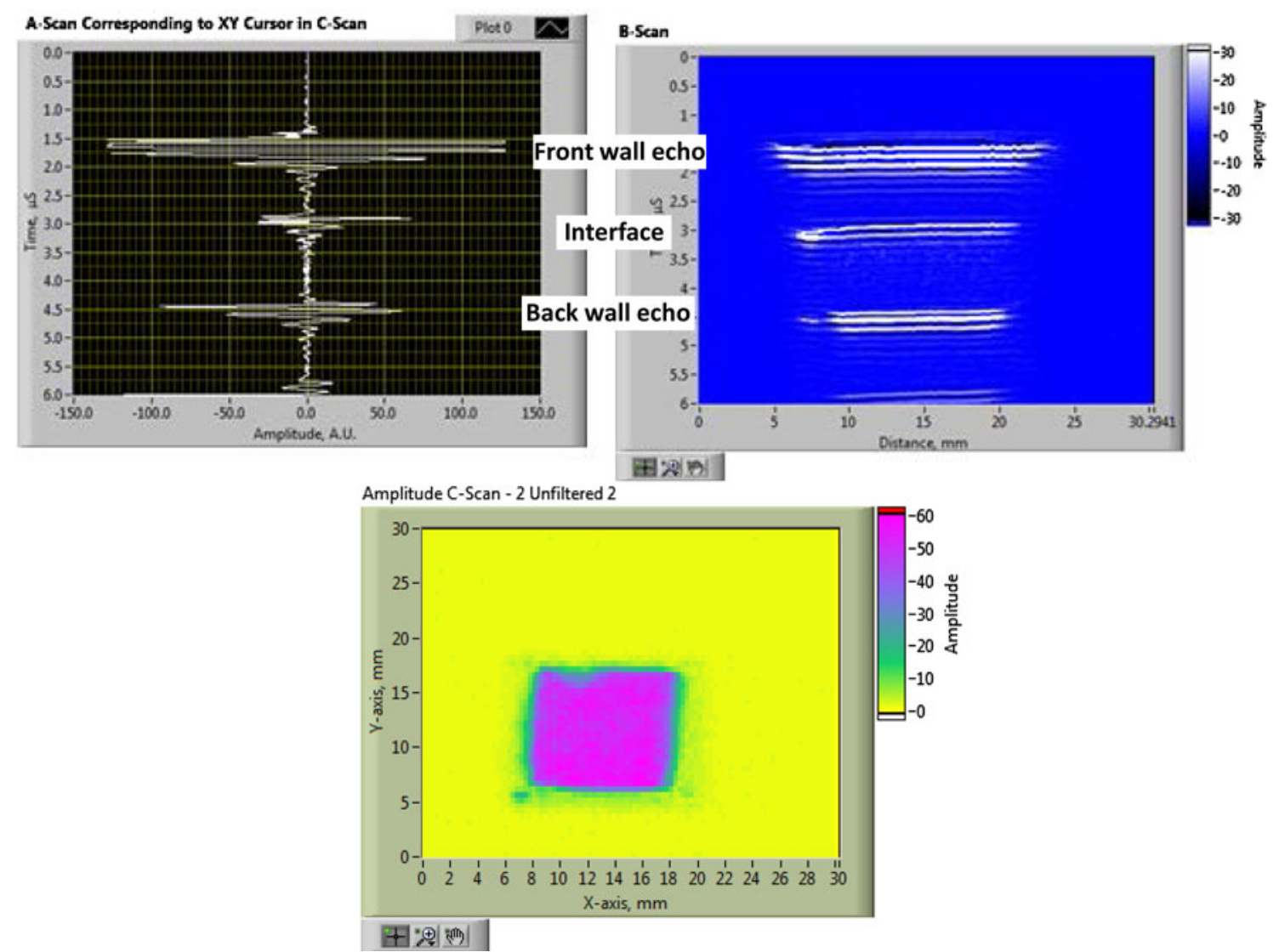

Fig. 2-Images of A, B, and C scan of ultrasonic testing of Ti-SS brazed joint with the beam incident on titanium plate.

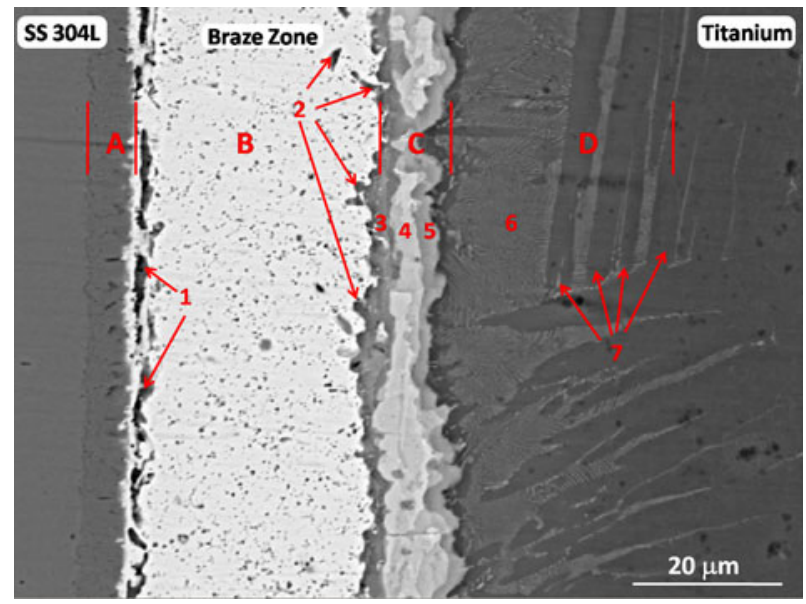

Fig. 3-Backscattered electron micrograph of the Ti-SS joint brazed at $1203 \mathrm{~K}\left(930^{\circ} \mathrm{C}\right)$. Different reaction zones are marked A through $\mathrm{D}$ and various phases formed in the BZ are marked 1 through 7.

various phases formed in the BZ, marked 1 through 5 in Figure 3, are listed in Table II. The details of microstructure and chemical analysis of different regions of the $\mathrm{BZ}$ are explained in Sections 1 through 4.

\section{SS braze alloy interface}

The layer marked A in Figure 3 was identified as a solid solution phase consisting of about 5 at.pct of $\mathrm{Al}$ and 21 at.pct of $\mathrm{Cr}$ in $\mathrm{Fe}$ along with 5.5 at.pet $\mathrm{Ni}$, which is reduced from about 10 at.pct in the bulk SS. Compositionally, this layer was identified as a solid solution of $\mathrm{Cr}, \mathrm{Ni}$, and $\mathrm{Al}$ in $\mathrm{Fe}$. The formation of this solid solution layer is facilitated by dissolution of $\mathrm{Ni}$ from SS into the molten braze alloy and simultaneous inward diffusion of $\mathrm{Al}$ from the braze alloy into the SS substrate, during the process of brazing.

The preferential dissolution of $\mathrm{Ni}$ as compared to $\mathrm{Fe}$ in the liquid phase of the $\mathrm{Ag}-\mathrm{Cu}$ system may be attributed to the higher solubility of $\mathrm{Ni}$ as compared to $\mathrm{Fe}$ in the liquid phase. ${ }^{[32,33]}$ Such dissolution of $\mathrm{Ni}$ (a $\gamma$ stabilizer) into the braze alloy and enrichment of $\mathrm{Al}$ (an $\alpha$ stabilizer) in the SS substrate may lead to a change in the crystal structure from fcc $\gamma$-Fe to bcc $\alpha$-Fe in the interdiffusion zone. Formation of a layer of $\alpha$-ferrite on the surface of austenitic SS, due to dissolution of $\mathrm{Ni}$ during interaction with molten metals such as $\mathrm{Pb}-\mathrm{Li}$ alloy $^{[34]}$ and $\mathrm{Pb}-\mathrm{Bi}$ eutectic alloy ${ }^{[35]}$ were reported earlier. Figure 5 shows the phase map and inverse pole figure maps of a region in the SS-Ti joint interface, acquired by the EBSD technique. The maps clearly show the absence of any bec $\alpha$-Fe phase at the SS-braze alloy interface. The scan within the BZ did not show a prominent orientation image map. Detailed TEM investigation of a region in layer $\mathrm{A}$, close to the SS-BZ interface, was also carried out. A bright-field TEM micrograph of the region is shown in Figure 6(a) and a typical selected area diffraction pattern (SADP) from 

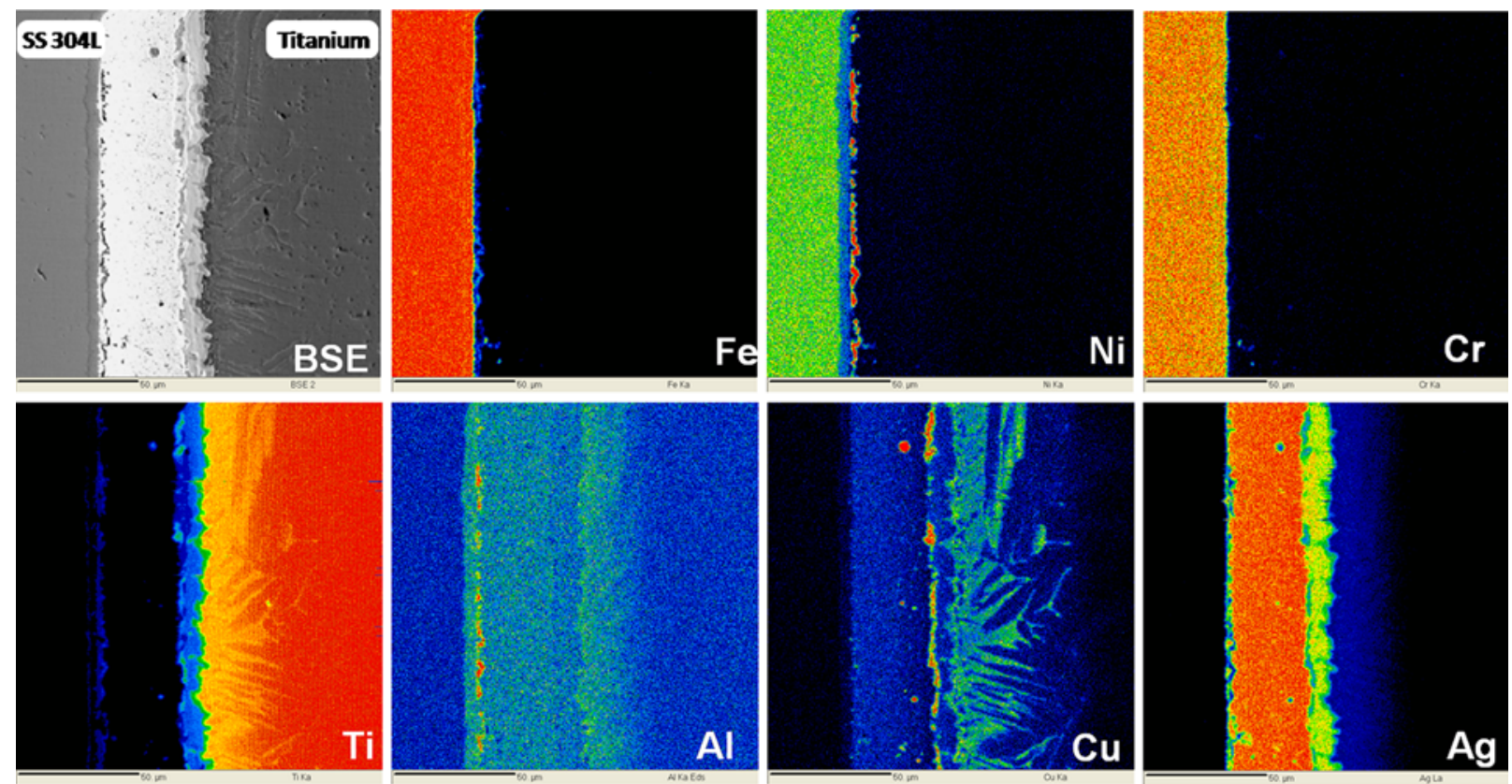

Fig. 4-X-ray maps of elements $\mathrm{Fe}, \mathrm{Ni}, \mathrm{Cr}, \mathrm{Ti}, \mathrm{Al}, \mathrm{Cu}$ and $\mathrm{Ag}$ along with the $\mathrm{BSE}$ image of a region at the Ti-SS joint interface, showing the distribution and variation in the relative concentrations of these elements in the BZ.

Table II. Chemical Composition (Atomic Percent) of the Phases Marked 1 through 5 in Fig. 3

\begin{tabular}{lcrrrrrrl}
\hline Phase Identity & $\mathrm{Ti}$ & $\mathrm{Cu}$ & $\mathrm{Ag}$ & $\mathrm{Al}$ & $\mathrm{Fe}$ & $\mathrm{Ni}$ & $\mathrm{Cr}$ & Probable Phase \\
\hline 1 & 22.4 & 1.6 & 2.6 & 18.8 & 17.2 & 37.8 & 2.2 & $(\mathrm{Ni}, \mathrm{Fe})_{2} \mathrm{TiAl}$ \\
2 & 18.4 & 76.8 & 3.4 & 0.4 & 0.5 & 0.4 & 0.2 & $\mathrm{Cu} \mathrm{C}_{4} \mathrm{Ti}$ \\
3 & 50.7 & 41.3 & 7.2 & 0.2 & 0.2 & 0.3 & 0.1 & $\mathrm{CuTi}$ \\
4 & 50.5 & 3.2 & 44.3 & 1.2 & 0.3 & 0.3 & 0.2 & $\mathrm{AgTi}$ \\
5 & 64.9 & 10.2 & 22.7 & 1.8 & 0.2 & 0.1 & 0.1 & $(\mathrm{Ag}, \mathrm{Cu}) \mathrm{Ti}{ }_{2}$ \\
\hline
\end{tabular}

the region, indexed with respect to the austenitic $\gamma-\mathrm{Fe}$ phase, is shown in Figure 6(b). No trace of any $\alpha-\mathrm{Fe}$ phase was noticed.

Just adjacent to the SS-braze alloy interface, a discontinuous layer of a phase, marked as 1 in Figure 3, was noticed. Chemical analysis showed that it was a Nirich phase with almost equal quantities of $\mathrm{Ti}, \mathrm{Fe}$, and $\mathrm{Al}$ (Table II). The X-ray image of Al in Figure 4 showed that the concentration of $\mathrm{Al}$ was maximum in this phase. Based on microanalysis, the phase was identified as the ternary phase $\mathrm{Ni}_{2} \mathrm{TiAl}$, with dissolved Fe.

\section{Titanium-braze alloy interface}

At the Ti-braze alloy interface, a zone of parallel layers of intermetallic compounds was found to form (marked as $\mathrm{C}$ in Figure 3). Three different continuous phase layers were delineated in this zone (phases 3 through 5 in Figure 3). The phase marked 2 formed as discrete islands at the interface between the unreacted braze alloy (layer B) and the reaction product (zone C). This phase 2 was identified as $\mathrm{Cu}_{4} \mathrm{Ti}$ and contained 0.4 at.pct $\mathrm{Al}$ and 3.4 at.pct $\mathrm{Ag}$. The $\mathrm{Ag}-\mathrm{Cu}-\mathrm{Ti}$ ternary diagram shows it to be saturated with Ag. ${ }^{[36,37]}$ Based on the microanalysis results, the phase layers labeled 3, 4, and 5 were identified as $\mathrm{CuTi}$, AgTi, and $(\mathrm{Ag}, \mathrm{Cu}) \mathrm{Ti}_{2}$ respectively. The chemical compositions of these phases are listed in Table II.

\section{Unreacted braze alloy}

The grain structure of the unreacted braze alloy layer B, could not be delineated using an SEM (Figure 3). However, TEM examination of this region revealed that it consists of nanocrystals of $\mathrm{Ag}-\mathrm{Cu}$ alloy. Figure 7 shows a typical bright-field TEM micrograph of this region along with a high resolution image, an electron diffraction pattern, and the EDS spectrum corresponding to the region. The Ag nanocrystals are about 20 to $30 \mathrm{~nm}$ in size. The formation of a ring-pattern in electron diffraction (Figure 7(c)) also confirms the formation of the nanocrystals. EDS analysis of this region showed that the layer contained about 4 at.pct $\mathrm{Cu}$ and a negligible amount of $\mathrm{Al}$ and Ti. The X-ray images in Figure 4 showed that almost the entire Ti and Al content of the brazing alloy was consumed in the interfacial reactions on either side. The reduction in the concentration of $\mathrm{Cu}$ in zone $\mathrm{B}$ to almost half of the initial amount of 5 wt.pct (8.2 at.pct) in the SilverABA braze alloy suggested that an appreciable quantity of $\mathrm{Cu}$ had diffused into Ti.

\section{Interdiffusion zone in $T i$}

On the Ti side of the BZ, Cu, Ag, and Al were found to diffuse into the Ti-base material up to a depth of about $40 \mu \mathrm{m}$, which is marked as zone D in Figure 3. This was also evident from the X-ray maps of Al, Ag, 

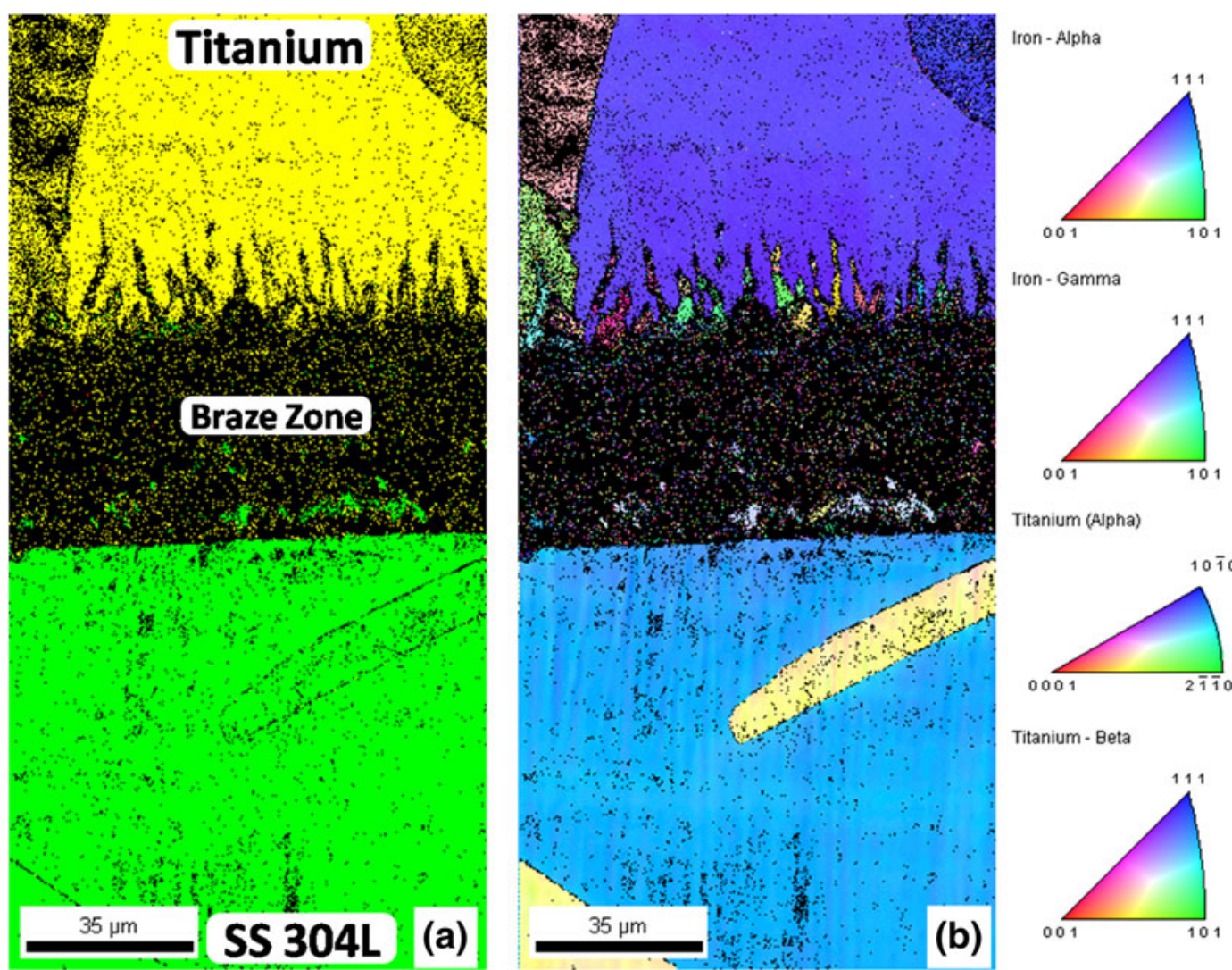

Iron-Gamma
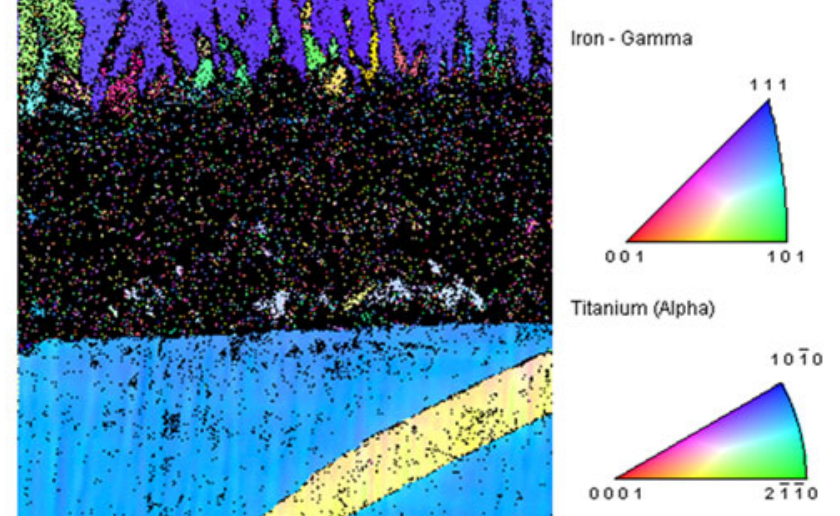

Phase
Iron - Alpha
Iron - Gamma
Titanium (Alpha)
Titanium - Beta

Fig. 5- (a) Phase maps and (b) inverse pole figures acquired using EBSD from a region at the Ti-SS joint interface.

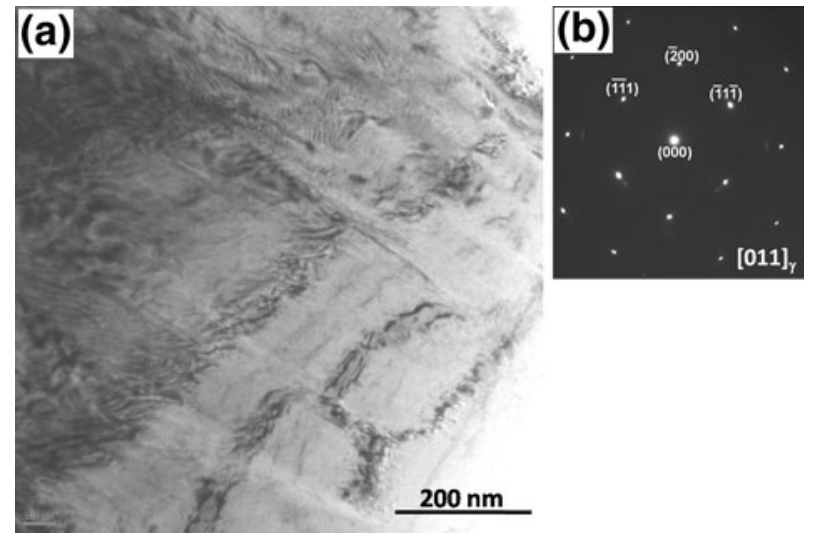

Fig. 6-(a) TEM micrograph of a region in SS, close to the SS-braze alloy interface (zone A in Fig. 3) and (b) SADP of the corresponding region indexed with respect to [011] zone axis of austenitic $(\gamma-\mathrm{Fe})$ phase.

and $\mathrm{Cu}$ in Figure 4. In most of the regions of this zone, a fine lamellar two-phase microstructure, marked as 6 , formed in colonies. Typical elongated plates of $\alpha$-Ti (phase 7 in Figure 3) were also found in zone D. The morphology of the two-phase microstructure resembled that of a eutectoid reaction product. The two-phase lamellar eutectoid product in zone D could be clearly resolved in an FESEM (Figure 8). The lamellae measured almost 5 to $6 \mu \mathrm{m}$ in length, and the interlamellar spacing was about $600 \mathrm{~nm}$. The relative variation in the concentration of the elements across the lamellar structure in Figure 8(b) shows that the dark matrix phase consisted primarily of $\mathrm{Ti}$ with a small amount of $\mathrm{Ag}$ and $\mathrm{Al}$, and the bright second-phase lamellae contained $\mathrm{Ti}$, $\mathrm{Cu}$, and $\mathrm{Ag}$.

The results of the TEM studies on the eutectoid product are shown in Figures 9 and 10. The two phases marked 1 and 2 in the bright-field microstructure in Figure 9(a) were identified as $\alpha-\mathrm{Ti}$ and $(\mathrm{Cu}, \mathrm{Ag}) \mathrm{Ti}_{2}$, respectively, by micro diffraction and EDS analysis. The electron diffraction patterns from the two phases were indexed with respect to $\alpha$-Ti and $\mathrm{CuTi}_{2}$ phases, as shown in Figures 9(b) and 9(c), respectively. The chemical composition obtained from the EDS analysis of the two phases is shown in Table III. The matrix $\alpha$-Ti phase contained about 2.4 at.pct $\mathrm{Ag}$ and about 4.5 at.pct Al, whereas, the lamellar intermetallic phase contained about 19.5 at.pct $\mathrm{Cu}$ and 8 at.pet $\mathrm{Ag}$ and negligible Al. It may be noted that Al being an $\alpha$ stabilizer, partitions in the matrix $\alpha$-phase. Since the concentration of $\mathrm{Cu}$ is more than that of $\mathrm{Ag}$ in 

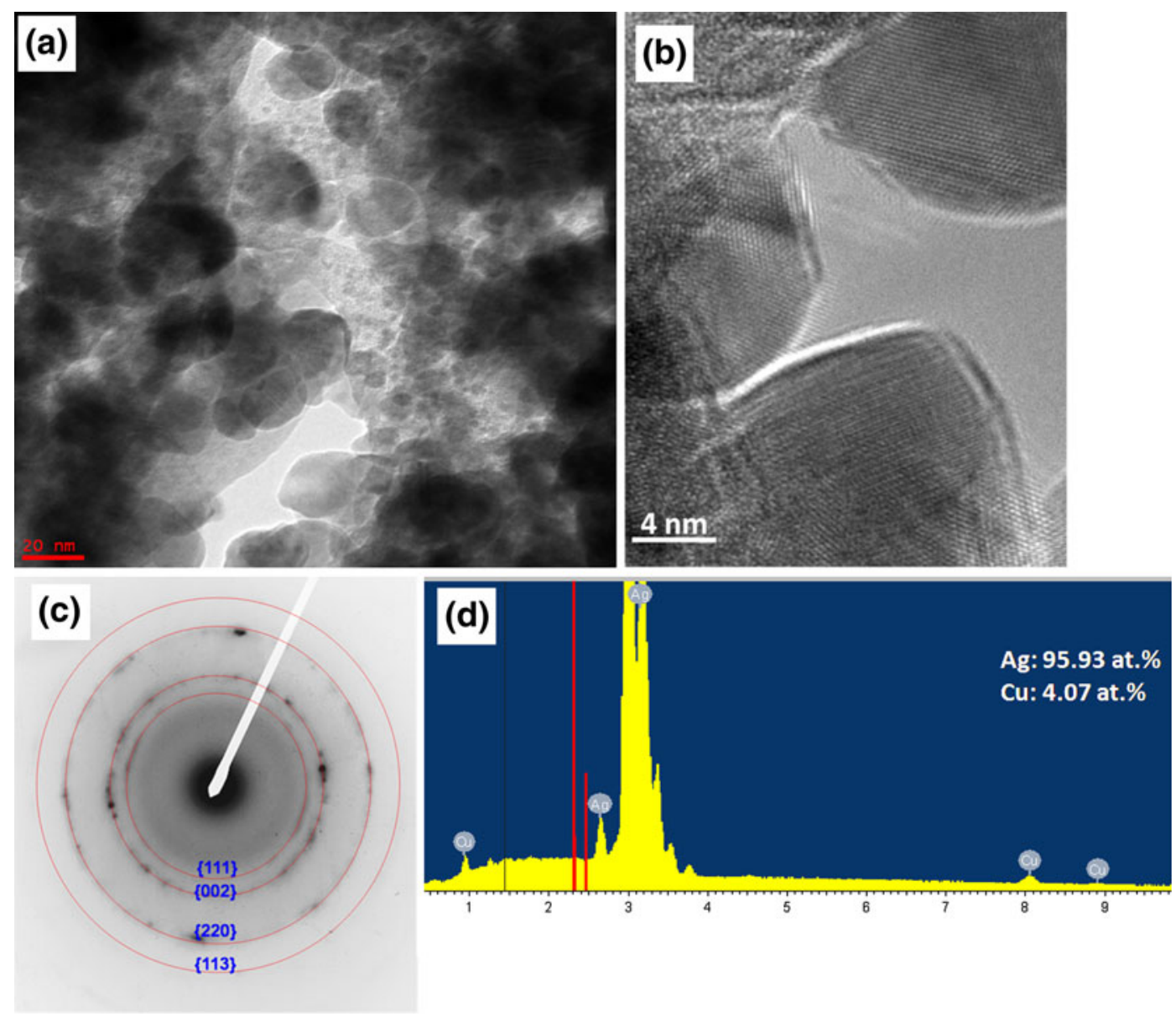

Fig. 7-TEM micrograph of the unreacted braze alloy (region B in Fig. 3) (a) low magnification bright field image, (b) high resolution image, (c) electron diffraction ring pattern and (d) EDS spectrum of this region.

the second phase, it is denoted as $(\mathrm{Cu}, \mathrm{Ag}) \mathrm{Ti}_{2}$. The larger spots in the SADP of the eutectoid product, a shown in Figure 10(b), were indexed in terms of the [2110] zone of $\alpha$-Ti. The weaker spots were indexed with respect to the [100] zone of the $\mathrm{CuTi}_{2}$ phase. The lattice parameters of $\mathrm{CuTi}_{2}$ and $\mathrm{AgTi}_{2}$ do not vary much, ${ }^{[37]}$ and since $\mathrm{Cu}$ is the major component occupying the 000 and $\frac{111}{222}$ sublattice positions of the $(\mathrm{Cu}, \mathrm{Ag}) \mathrm{Ti}_{2}$ phase, the lattice parameters of $\mathrm{CuTi}_{2}$ were used for indexing the SADP. The faint spots, circled in Figure 10(b), were the superlattice reflections from planes of the $(\mathrm{Cu}, \mathrm{Ag}) \mathrm{Ti}_{2}$ phase, (002) and (004), for example. The orientation relationship (OR) between the two phases in the eutectoid product was determined to be

$$
(0001)_{\alpha} \|(0 \overline{1} 3)_{\mathrm{CuTi}_{2}} \text { and }[2 \overline{110} 0]_{\alpha} \|[\overline{1} 00]_{\mathrm{CuTi}_{2}}
$$

The indexed SADP in Figure 10(c) further revealed that the $(\mathrm{Cu}, \mathrm{Ag}) \mathrm{Ti}_{2}$ phase is internally twinned along the (013) plane. Figure 10(d) shows the dark-field image acquired using the reflections from the $(\mathrm{Cu}, \mathrm{Ag}) \mathrm{Ti}_{2}$ phase.

\section{Microhardness}

The variation in microhardness across the $\mathrm{BZ}$ is shown in Figure 11. It may be noted from the profile that the hardness rises to about $260 \mathrm{VHN}$ in the $\mathrm{Ni}$ depleted layer formed at the SS/braze-alloy interface (zone A). The hardness in the unreacted braze alloy layer (zone B) showed a very low hardness of about 70 to $80 \mathrm{VHN}$, which was very close to that of pure $\mathrm{Ag}$. The hardness was found to be highest (430 to $450 \mathrm{VHN}$ ) in zone $\mathrm{C}$, where the layers of intermetallic phases were formed. The eutectoid region marked 6 in Figure 3 also showed higher hardness values as compared to the base Ti material.

\section{Crack Formation in Bending Tests}

Figure 12 shows the microstructure of the cross section of a $\mathrm{SS} / \mathrm{Ti}$ brazed joint after subjecting to bending stresses across the bond line. The position and path of propagation of the cracks are outlined with a dashed line in Figure 12(a). The overall microstructure shows that the crack propagates mostly though the Tibraze alloy interface. However, at some locations, as can be seen in Figure 12(a), the crack tends to cross over to the SS side of the joint and propagates for a short distance through the SS/BZ interface, before again crossing over to the $\mathrm{BZ} / \mathrm{Ti}$ interface. 


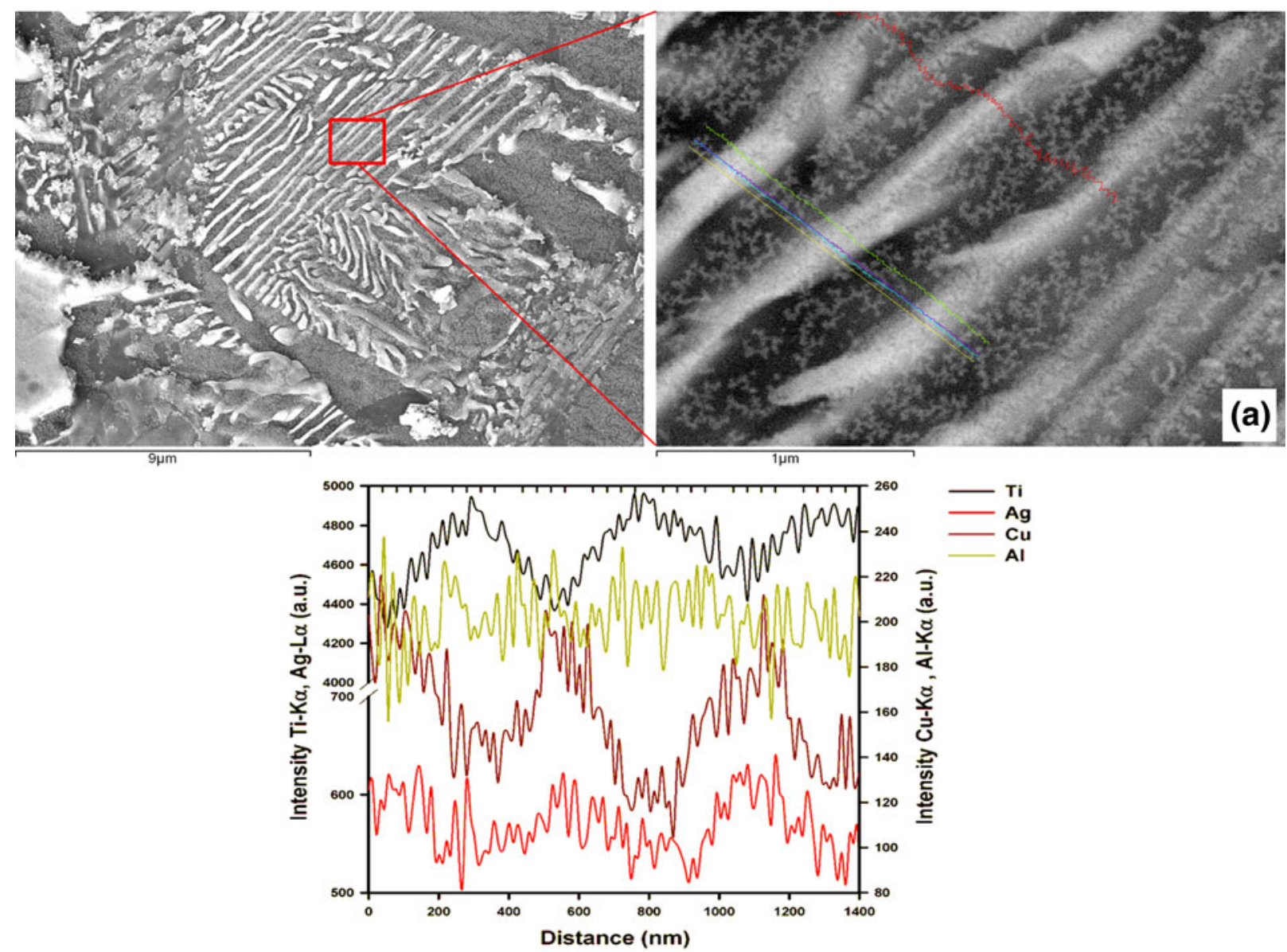

(b)

Fig. 8- (a) FESEM micrograph of the eutectoid formed within region 6 in Fig. 3, and (b) variation in X-ray intensity of Cu-K $\alpha$, Ti-K $\alpha$, Ag-L $\alpha$ and $\mathrm{Al}-\mathrm{K} \alpha$ across the alternate lamellae in the eutectoid.

\section{DISCUSSION}

Brazing is a thermodynamically driven but kinetically controlled process in which the molten filler alloy wets the surface of base materials and chemically interacts with them. Such interactions at the solid-liquid interfaces result in formation of either solid solutions or intermetallic phases due to interdiffusion of elements, leading to a metallurgical bond between the two joining materials. In the context of the present brazing study, the result of the interfacial reactions may be summarized as follows:

(a) formation of a Ni-depleted solid solution layer and a discontinuous phase of $\mathrm{Ni}_{2} \mathrm{TiAl}$ at the SS-braze alloy interface;

(b) formation of three contiguous layers of intermetallics, CuTi, AgTi, and $(\mathrm{Ag}, \mathrm{Cu}) \mathrm{Ti}_{2}$ at the Ti-braze alloy interface; and

(c) formation of a large $\beta-\mathrm{Ti}(\mathrm{Ag}, \mathrm{Cu})$ solid solution layer on the Ti-side, which transformed to a twophase eutectoid structure consisting of $\alpha$-Ti and $(\mathrm{Cu}, \mathrm{Ag}) \mathrm{Ti}_{2}$ upon cooling.

The different reactions involved during the entire brazing process may be categorized as those occurring during brazing and those taking place during the subsequent cooling process, as mentioned subsequently. Figure 13 shows a schematic representation of the site and sequence of these reactions.

Reactions during the brazing:

(a) Melting of the Silver-ABA braze alloy in the range 1133 to $1185 \mathrm{~K}\left(860{ }^{\circ} \mathrm{C}\right.$ to $\left.912{ }^{\circ} \mathrm{C}\right)$.

(b) Dissolution of $\mathrm{Fe}, \mathrm{Ni}$, and $\mathrm{Cr}$ from $\mathrm{SS}$ into the molten braze alloy and formation of a Ni-depleted interdiffusion layer of $\gamma-\mathrm{Fe}(\mathrm{Cr}, \mathrm{Ni}, \mathrm{Al})$ solid solution due to the diffusion of $\mathrm{Al}$ into SS.

(c) Dissolution of $\mathrm{Ti}$ into the molten braze alloy and diffusion of $\mathrm{Cu}$ and $\mathrm{Ag}$ into $\beta$-Ti, leading to the formation of a layer of $\beta-\mathrm{Ti}(\mathrm{Ag}, \mathrm{Cu})$ solid solution on the Ti side of the BZ.

(d) Migration of $\mathrm{Fe}, \mathrm{Ni}$, and $\mathrm{Cr}$ to the $\mathrm{BZ} / \mathrm{Ti}$ interface by liquid-phase diffusion in the molten braze alloy.

(e) Formation of contiguous layers of $\mathrm{CuTi}$ (phase 3), $\mathrm{AgTi}$ (phase 4), and (Ag, Cu) $\mathrm{Ti}_{2}$ (phase 5) due to the solid-liquid interaction at the BZ/Ti interface.

Reactions during solidification and cooling:

(a) Rejection of excess $\mathrm{Fe}$ and $\mathrm{Ni}$ from the solidifying $\mathrm{Ag}-\mathrm{Cu}$ liquid alloy due to their low solubility in 


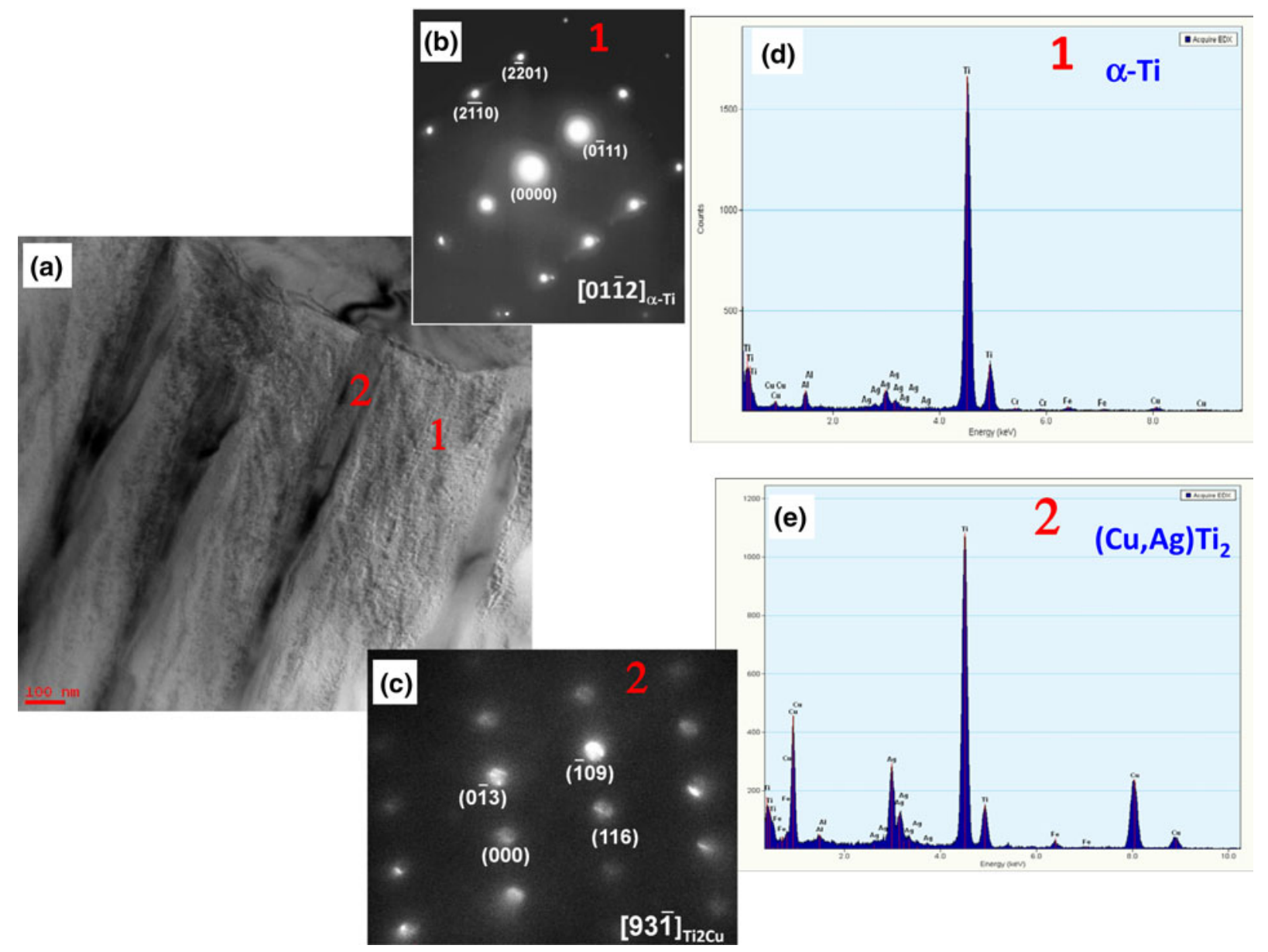

Fig. 9- (a) TEM micrograph of the eutectoid of $\alpha$ - Ti and $(\mathrm{Cu}, \mathrm{Ag}) \mathrm{Ti}_{2}$ in region 6 . The micro-diffraction patterns from the spots marked $(b) 1(\alpha-$ $\mathrm{Ti})$ and $(c) 2\left((\mathrm{Cu}, \mathrm{Ag}) \mathrm{Ti}_{2}\right)$ in the micrograph and $(d)$ and $(e)$ the EDS spectra, respectively.

the solid state and formation of $(\mathrm{Ni}, \mathrm{Fe})_{2} \mathrm{TiAl}$ phase at the SS/BZ interface, by combining with $\mathrm{Ti}$ and $\mathrm{Al}$ of the braze alloy.

(b) Eutectoid transformation of the $\beta-\mathrm{Ti}(\mathrm{Cu}, \mathrm{Ag})$ solid solution phase to $\alpha$ - $\mathrm{Ti}$ and $(\mathrm{Ag}, \mathrm{Cu}) \mathrm{Ti}_{2}$ in the temperature range 1063 to $1123 \mathrm{~K}\left(790{ }^{\circ} \mathrm{C}\right.$ to $\left.850{ }^{\circ} \mathrm{C}\right)$.

(c) Formation of $\mathrm{Cu}_{4} \mathrm{Ti}$ (phase 2) during cooling due to low solubility of $\mathrm{Ti}$ in solid $\mathrm{Ag}$ and progressively decreasing solubility of $\mathrm{Ti}$ in $\mathrm{Cu}$, as it cools to room temperature.

\section{A. Microstructural Evolution at the Interfaces}

\section{SS-braze alloy interface}

As mentioned earlier, adjacent to the SS-braze alloy interface, $\mathrm{Ni}_{2} \mathrm{TiAl}$ phase with about 17.2 at.pct dissolved $\mathrm{Fe}$ (marked phase 1 in Figure 2) formed as an elongated discontinuous islands. Both the ternary systems of Ni-Ti$\mathrm{Al}^{[38-40]}$ and $\mathrm{Fe}-\mathrm{Ti}-\mathrm{Al}^{[41,42]}$ show a prominent presence of ternary Heusler phases with $\mathrm{L} 2{ }_{1}$ structure, i.e., $\mathrm{Ni}_{2} \mathrm{TiAl}$ and $\mathrm{Fe}_{2} \mathrm{TiAl}$, respectively over a large solubility range in the respective phase diagrams. ${ }^{[38,40]}$ Kainuma et al. ${ }^{[43]}$ and more recently Yan et al., ${ }^{[44]}$ reported detailed studies on the phase stability of the Ni-Fe-Ti-Al quarternary system. Their work highlighted that the $\mathrm{Ni}_{2} \mathrm{TiAl}$ and
$\mathrm{Fe}_{2} \mathrm{TiAl}$ phases show unlimited mutual solid solubility, and hence can be written as $(\mathrm{Ni}, \mathrm{Fe})_{2} \mathrm{TiAl}$. Further, $\mathrm{Fe}$ exhibited a preference to partition to the $\mathrm{Ni}_{2} \mathrm{TiAl} \mathrm{L} 2_{1}$ phase, rather than the NiAl B2 phase. ${ }^{[43]}$ In contrast to the present observations, formation of a layer of the FeTi intermetallic phase on the surface of SS due to its reaction with $\mathrm{Ag}-\mathrm{Cu}$ eutectic alloy ${ }^{[9]}$ or $\mathrm{Ag}$-based active brazing alloy ${ }^{[45]}$ was reported earlier. Such a difference in interaction and phase formation at the SS-braze alloy interface could be due to the fact that in none of these cases was $\mathrm{Al}$ a constituent element of the braze alloys. As mentioned earlier, the preferential dissolution of $\mathrm{Ni}$ during the process of brazing leads to the formation of the Ni-depleted interdiffusion layer $\mathrm{A}$ in the SS/BZ interface. During solidification of the liquid braze alloy at the end of brazing, the dissolved $\mathrm{Ni}$ and $\mathrm{Fe}$ are rejected out of the $\mathrm{Ag}-\mathrm{Cu}$ liquid phase, owing to almost negligible solubility in solid state. ${ }^{[46,47]}$ In the presence of $\mathrm{Al}$ and $\mathrm{Ti}$ in the liquid braze alloy, the excess $\mathrm{Fe}$ and $\mathrm{Ni}$, therefore, precipitate as the $(\mathrm{Ni}, \mathrm{Fe})_{2} \mathrm{TiAl}$ phase in the vicinity of the SS surface.

\section{Titanium-braze alloy interface}

In contrast to the SS-braze alloy interface, three contiguous layers of intermetallic compounds, CuTi, 

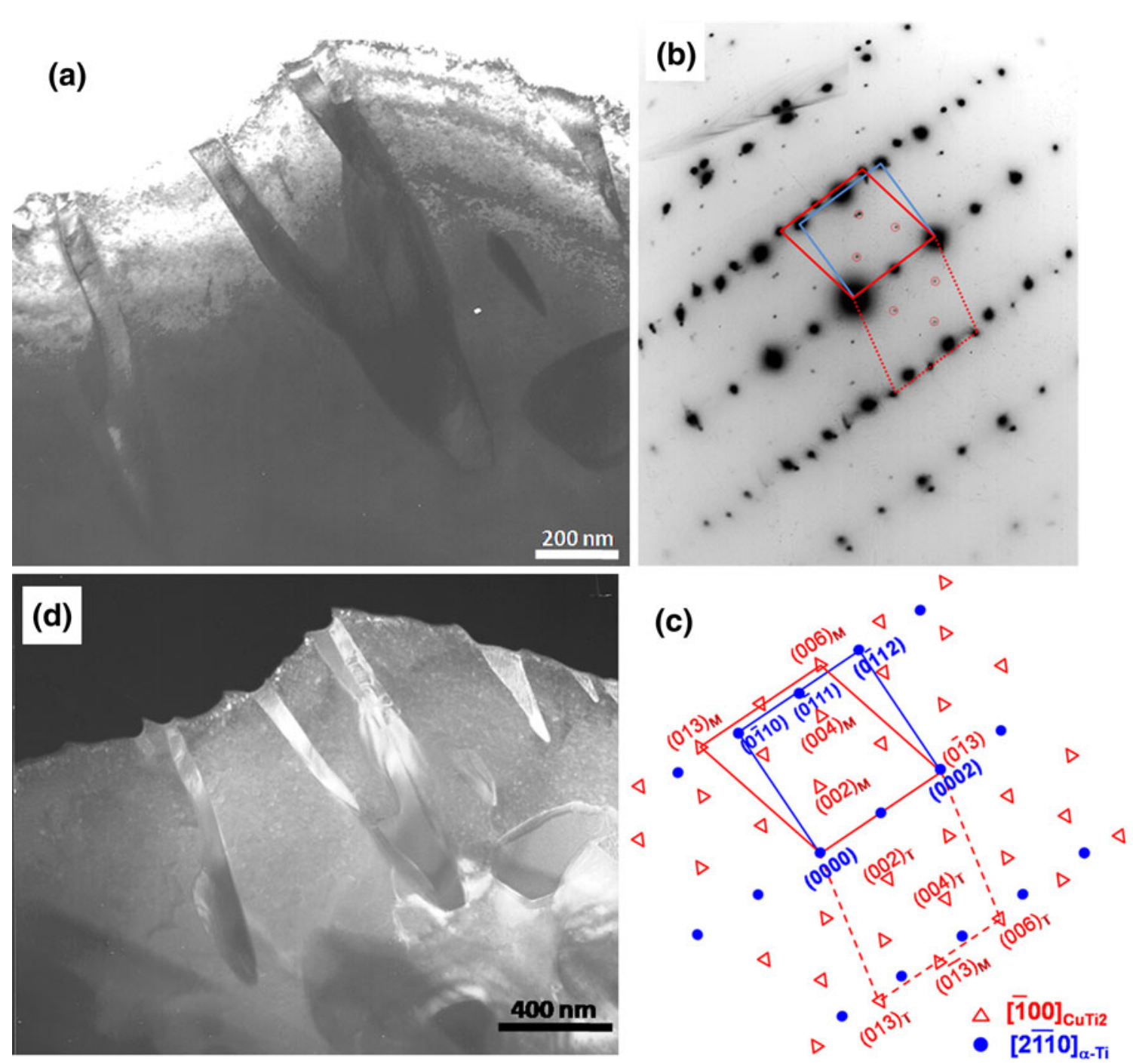

Fig. 10 - (a) Bright field micrograph of the eutectoid structure, $(b)$ selected area diffraction pattern, $(c)$ key to the SADP, and (d) dark field micrograph using the second-phase reflections. Superlattice reflections from the second phase are marked by red circles in (b).

Table III. Chemical Composition (Atomic Percent) of Individual Phases in the Eutectoid Product in Region 6 of Fig. 3, Determined Using EDS in TEM

\begin{tabular}{lcccc}
\hline Elements & $\mathrm{Ti}$ & $\mathrm{Cu}$ & $\mathrm{Ag}$ & $\mathrm{Al}$ \\
\hline$\alpha$-Ti & 91.6 & 1.5 & 2.4 & 4.5 \\
$(\mathrm{Cu}, \mathrm{Ag}) \mathrm{Ti}_{2}$ & 72.0 & 19.5 & 8.0 & 0.5 \\
\hline
\end{tabular}

$\mathrm{AgTi}$, and $(\mathrm{Ag}, \mathrm{Cu}) \mathrm{Ti}_{2}$ (marked 3, 4, and 5, respectively, in Figure 3), formed at the Ti-braze alloy interface. The presence of small concentrations of $\mathrm{Fe}, \mathrm{Ni}$, and $\mathrm{Cr}$ in these phases, ranging within 0.1 to 0.3 at.pct (Table II) was observed. The diffusion coefficient of different elements in liquid Ag range between 1 and $8 \times 10^{-9}$ $\mathrm{m}^{2} / \mathrm{s}^{[48]}$ An estimate of the diffusion length (approximated as $\sqrt{D t}$, where $D$ is the diffusion coefficient and $t$ is the time of diffusion) for the present experiments showed it to be more than $1 \mathrm{~mm}$, which is two orders of magnitude higher than the $\mathrm{BZ}(\sim 30 \mu \mathrm{m})$. Therefore, the

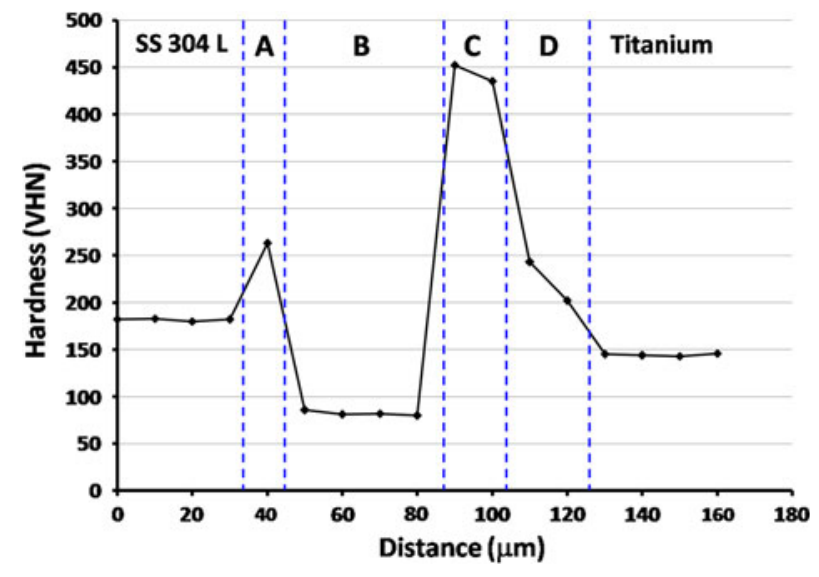

Fig. 11-Variation in the microhardness across the BZ between SS and Ti.

presence of $\mathrm{Fe}, \mathrm{Ni}$, and $\mathrm{Cr}$ in the intermetallic phases within zone $\mathrm{C}$ may be attributed to the dissolution of SS due to the solid-liquid interaction and subsequent 


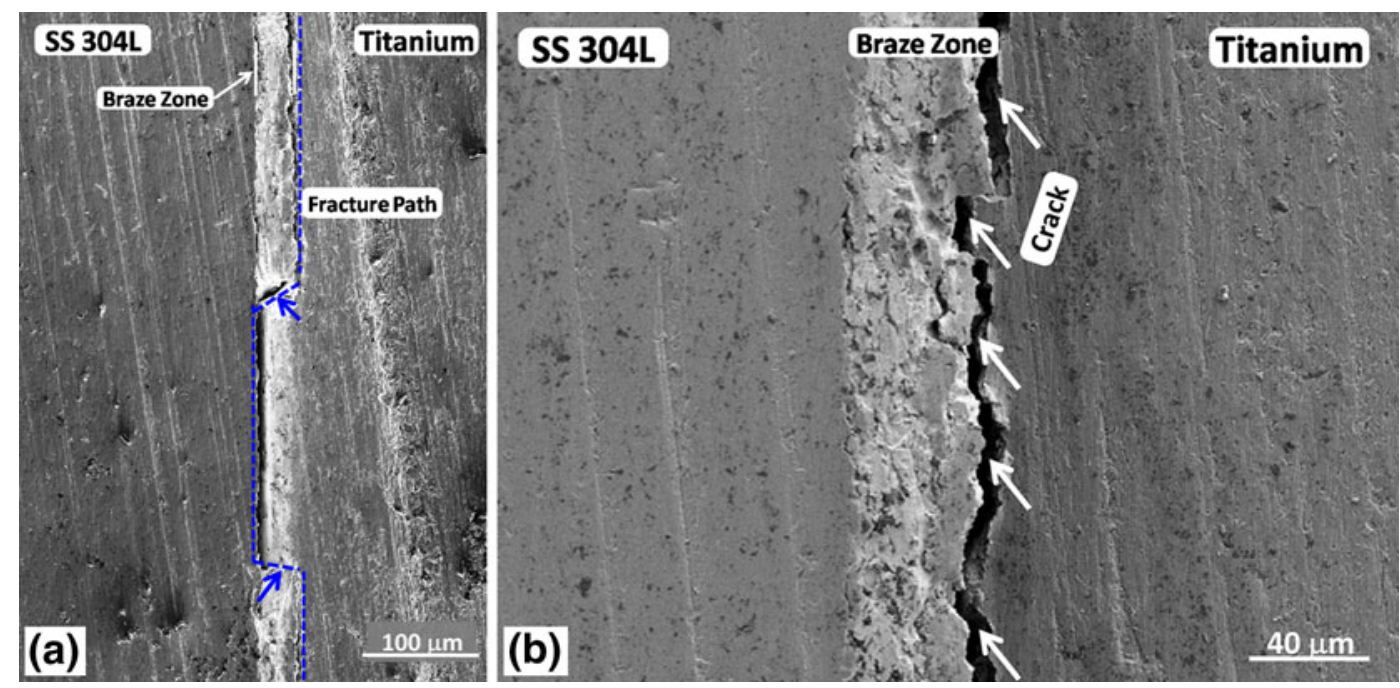

Fig. 12-Microstructure of Ti-SS brazed joint interface subjected to bending stress across the bond line at $(a)$ lower magnification and $(b)$ higher magnification. The path of propagation of the crack is outlined by a dashed line. Arrows indicate (a) the change in direction of cracks and (b) the path of failure.

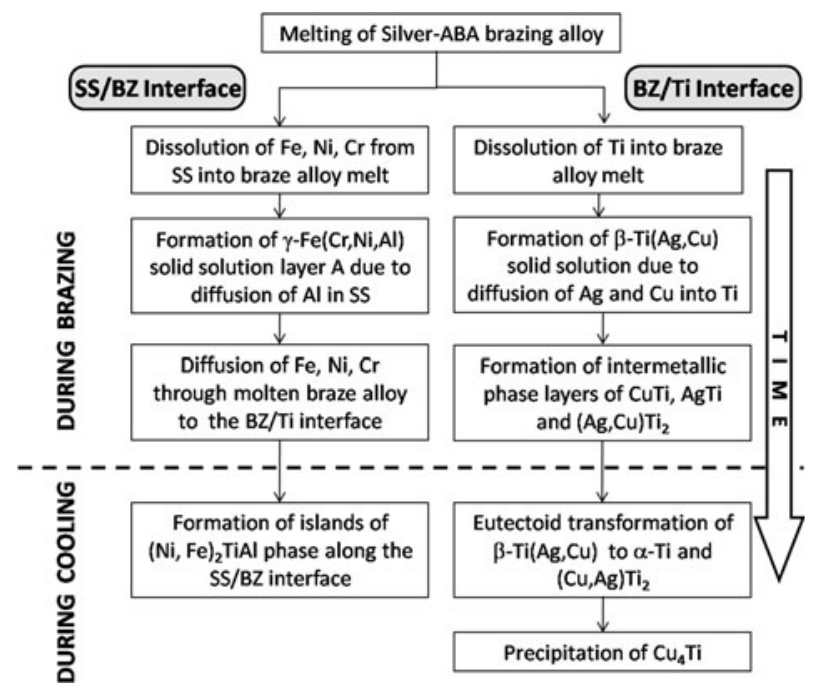

Fig. 13-Schematic representation of the sequence of reactions taking place during the entire brazing cycle of SS and titanium using Silver-ABA alloy. The reactions occurring during brazing and during subsequent cooling are delineated.

diffusion of these species to the BZ/Ti interface, through the molten braze alloy.

The binary phases $\mathrm{AgTi}_{2}$ and $\mathrm{CuTi}_{2}$ are known to share a common body-centered-tetragonal (bct) crystal structure denoted by $t I 6\left(\mathrm{MoSi}_{2}\right.$ type $) .{ }^{[37]}$ Although both these compounds are stoichiometric with negligible solubility range, the mutual solubility of these compounds is unlimited. This may be attributed to closely matching lattice parameters of the compounds $\left(\mathrm{AgTi}_{2}: a\right.$ $=2.952 \AA$ and $c=11.85 \AA$ and $\mathrm{CuTi}_{2}: a=2.953 \AA$ and $c=10.73 \AA$ ). The $\mathrm{Cu}$ and $\mathrm{Ag}$ types of atoms share a common sublattice and hence can be denoted as $(\mathrm{Ag}, \mathrm{Cu}) \mathrm{Ti}_{2}$.
The sequence of formation of these phases is represented by tracing the diffusion path on the $\mathrm{Ag}-\mathrm{Cu}-\mathrm{Ti}$ ternary phase diagram in Figure 14. The dotted line AB represents the joining of the end-member compositions. It was noted that the diffusion path crossed the line joining the end-members twice (Figure 14), and each cross-over point is represented by the interfaces on either side of the AgTi phase layer. In principle, the diffusion path needs to cross the line joining the end members at least once, to maintain the mass balance of the elements in the diffusion zone, which is one of the 17 theorems on diffusion paths in ternary systems put forward by Kirkaldy and Brown ${ }^{[49]}$ and Kirkaldy and Young $^{[50]}$ in their classical work and reaffirmed recently by Morral. ${ }^{[51]}$

The concentration of $\mathrm{Ag}$ in $\mathrm{CuTi}$ and that of $\mathrm{Cu}$ in AgTi were estimated as 7.2 and 3.2 at.pct respectively, which closely matched with the composition in the ternary phase diagram. ${ }^{[36,37]}$ Both CuTi and AgTi have finite solubility range and hence, are not expected to be very brittle. In fact, previous studies demonstrated that the formation of the AgTi phase in the BZ does not cause a deterioration in the bond strength of the joint. ${ }^{[45,52,53]}$ The earlier work on brazing of $\mathrm{Ti}$ to $\mathrm{SS}^{[7,45]}$ and to carbon steel ${ }^{[22-25]}$ using $\mathrm{Ag}-\mathrm{Cu}$ eutectic or active metal brazing alloy containing $\mathrm{Ag}, \mathrm{Cu}$, and $\mathrm{Ti}$ showed that at the $\mathrm{Ti} /$ braze alloy interface, primarily $\mathrm{Cu}-\mathrm{Ti}$ based intermetallic compounds are formed. $\mathrm{CuTi}, \mathrm{CuTi}_{2}$, $\mathrm{Cu}_{4} \mathrm{Ti}_{3}$, and $\mathrm{Cu}_{2} \mathrm{Ti}$ are the main phases that are reported to form by solid-liquid reaction of $\mathrm{Ag}-\mathrm{Cu}$ based braze alloys with $\mathrm{Ti}^{[6,7,22-24,45,54]}$ However, it is worth mentioning that in the presence of such high concentration of Ag ( $~ 93$ at.pct), formation of Ag-rich intermetallic phases by reaction with $\mathrm{Ti}$ is not unexpected. Moreover, formation of only $\mathrm{Cu}$-Ti compounds, i.e., one side of the line joining end member compositions (Figure 14) is not allowed from the mass-balance viewpoint. ${ }^{[49]}$ This justifies the formation of AgTi phase in the diffusion zone. 


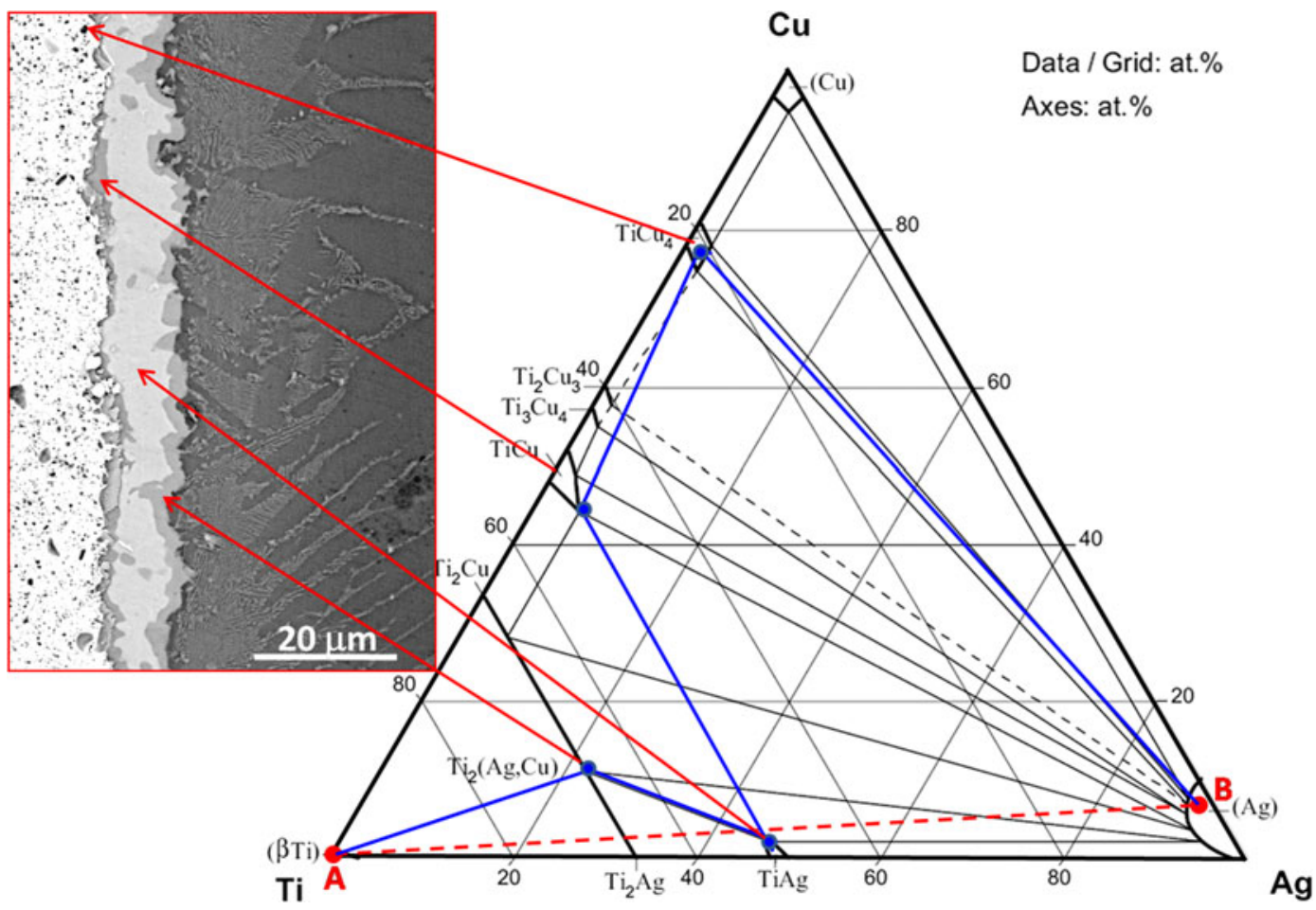

Fig. 14 - Ternary phase diagram of Ag-Cu-Ti at $973 \mathrm{~K}\left(700^{\circ} \mathrm{C}\right){ }^{[37]}$ in which the end member compositions at the Ti-braze alloy interface are joined with dashed line $\mathrm{AB}$, the diffusion path is traced with a solid line, and the phases formed are marked with filled dots. Respective locations of the phases in the microstructure are pointed using an arrow.

\section{B. Eutectoid Reaction in the Interdiffusion Zone}

During the brazing operation at $1203 \mathrm{~K}\left(930^{\circ} \mathrm{C}\right)$, Ti transformed to bec $\beta$-Ti phase $[\alpha-\beta$ transus at $1156 \mathrm{~K}$ $\left.\left(883^{\circ} \mathrm{C}\right)\right]$. The low activation energy for diffusion of $\mathrm{Cu}$ $\left(Q=122.3 \mathrm{~kJ} / \mathrm{mol}^{[55]}\right), \operatorname{Ag}\left(Q=180 \mathrm{~kJ} / \mathrm{mol}^{[56]}\right)$, and $\mathrm{Al}$ $\left(Q=150 \mathrm{~kJ} / \mathrm{mol}^{[57]}\right)$ in $\beta$-Ti and high solubility of $\mathrm{Cu}$, $\mathrm{Ag}$ and $\mathrm{Al}^{[58,59]}$ promoted the diffusion of these species in the $\beta$-Ti phase. It may be noted that a finite amount of solid-state diffusion would also occur during the course of heating of the braze assembly. However, its effect would be of any practical significance only at temperatures, nearing the peak brazing temperature. It is also worth noting that such solid-state diffusion contributes to the extent of the interfacial reactions, though marginally, but does not alter the mechanism of these reactions.

During the process of cooling after brazing, the Ti base material would revert back to hep $\alpha$-Ti phase below the $\alpha-\beta$ transus. However, in the interdiffusion region D, due to the high concentration of $\beta$ stabilizers $(\mathrm{Cu}, \mathrm{Ag})$, the phase transformation would be partially suppressed resulting in a two-phase $(\alpha+\beta)$ region. Such a transformation involved formation of typical plates of $\alpha$-Ti in colonies, label 7 in Figure 2 and the untransformed $\beta$-Ti phase remained in the inter-plate regions. The $\mathrm{Cu}$ and $\mathrm{Ag}$ present in this region partitioned in the untransformed $\beta$-Ti phase, owing to its higher solubility in this phase. Further cooling led to the fine two-phase eutectoid reaction product with lamellar morphology (region 6 in Figure 2). Formation of such two-phase regions on the Ti side is a commonly observed phenom- enon during the brazing of $\mathrm{Ti}$ with Ag-based alloys. ${ }^{[7,23,25]}$ However, due to the fineness of the microstructure (interlamellar distance being in the submicron range), characterization of the individual constituent phases with respect to chemistry and crystal structure were not attempted in the earlier reports and were referred to as a mixture of $\alpha$ and $\beta$ phases. ${ }^{[7,23,25,54]}$ $\mathrm{Jaffee}^{[60]}$ classified the systems of Ti-Ag and $\mathrm{Ti}-\mathrm{Cu}$ as active-eutectoid systems, which implies that the $\beta$-Ti phase in these systems cannot be retained even on quenching. It was reported that even during rapid quenching, the $\beta$-phase undergoes eutectoid decomposition in near-eutectoid Ti-Cu alloys. ${ }^{[61,62]}$ Therefore, during the process of cooling of the Ti-SS brazed joint, the $\beta$ - Ti $(\mathrm{Ag}, \mathrm{Cu})$ solid solution, formed in region $\mathrm{D}$, underwent eutectoid decomposition to the product phases $\alpha$ - Ti and $(\mathrm{Cu}, \mathrm{Ag}) \mathrm{Ti}_{2}$ in the form of colonies of lamellar aggregate.

It is interesting to note that Bhaskaran et al. ${ }^{[62]}$ also reported an orientation relationship between $\alpha$-Ti and $\mathrm{CuTi}_{2}$ in the decomposition product of a rapidly solidified near-eutectoid Ti-Cu binary alloy, identical to that in the present eutectoid product. They also observed twin-related reflection spots in the SADP from the $\mathrm{CuTi}_{2}$ phase, similar to those in Figure 10(b). Therefore, it may be concluded that the rate of cooling and the presence of $\mathrm{Ag}$ in the system has little influence on the crystallographic orientation of formation of the eutectoid product. However, Williams et al. ${ }^{[63]}$ showed that ageing of supersaturated solid solution of $\alpha$-Ti in the temperature range $673 \mathrm{~K}$ to $773 \mathrm{~K}\left(400{ }^{\circ} \mathrm{C}\right.$ to 
$500{ }^{\circ} \mathrm{C}$ ) resulted in the formation of incoherent $\mathrm{CuTi}_{2}$ precipitates throughout the matrix, through the classical process of homogeneous nucleation and growth. Interestingly, the SADP produced from specimens of aged alloys (Figure 7 of Reference 63) are very similar to Figure 10(b), with the difference that the twin-related spots observed in the latter case were absent in the former. The orientation relationship, established by them, between $\alpha$-Ti and $\mathrm{CuTi}_{2}$ is: $(0001)_{\alpha} \|(0 \overline{1} 3)_{\mathrm{CuTi}_{2}}$ and $[1 \overline{2} 10]_{\alpha} \|[100]_{\mathrm{CuTi}_{2}}$, which is consistent with the present observations. Mukhopadhyay et al. ${ }^{[64]}$ showed that in an analogous system of $\mathrm{Zr}-\mathrm{Cu}$, the $\beta$ - $\mathrm{Zr}$ phase also exhibits active eutectoid decomposition to $\alpha-\mathrm{Zr}$ and $\mathrm{CuZr}_{2}$ related with a similar OR: $(0001)_{\alpha} \|(013)_{\{\mathrm{CuZr} 2}$ and $(0001)_{\alpha} \|(013)_{\mathrm{CuZr}_{2}}$ and $[\overline{1} 100]_{\alpha} \|[0 \overline{3} 1]_{\mathrm{CuZr}_{2}}$.

\section{Fracture Behavior}

As mentioned earlier, the cracks in the joints, subjected to bending stress, were found to propagate predominantly through the $\mathrm{BZ} / \mathrm{Ti}$ interface. This could be attributed to the inherent brittleness of the $(\mathrm{Ag}, \mathrm{Cu}) \mathrm{Ti}_{2}$ phase. Similar observations were also reported by Ganjeh et al. ${ }^{[54]}$ in $\mathrm{Ti}$ brazed with $\mathrm{Ag}$ $\mathrm{Cu}$-based alloy. Microstructure and X-ray diffraction of the fractured surfaces confirmed that the failure in these joints were due to initiation and propagation of cracks in the brittle $\mathrm{CuTi}_{2}$ phase, which led to a quasi-cleavage type fracture. ${ }^{[54]}$ However, at certain locations, as shown in Figure 12(a), a tendency of crossing over of the crack to the SS/BZ interface was also observed. A change in the direction of propagation of the crack indicated that possibly the formation of the discontinuous ternary intermetallic $(\mathrm{Ni}, \mathrm{Fe})_{2} \mathrm{TiAl}$ phase 1 , at the $\mathrm{SS} / \mathrm{BZ}$ interface, allows the crack to propagate through this interface at certain locations.

In the absence of data on the ductility of the two responsible intermetallic compounds, the brittleness of the two intermetallic phases can be compared from the crystal structure and slip system viewpoint. In ordered $\mathrm{L} 2_{1}$ structured compounds such as $\mathrm{Ni}_{2} \mathrm{TiAl}$, slip is observed to occur primarily along the $\langle 110\rangle$ directions and on the $\{110\}$ and $\{011\}$ planes, ${ }^{[65]}$ over a wide range of temperature. This is because the critical resolved shear stress is lowest in the $\{\overline{1} 10\}\langle 110\rangle$ slip system. ${ }^{[65]}$ Additionally, planar slip also appears to occur in the $\mathrm{Ni}_{2} \mathrm{TiAl}$ compounds on the $\{110\}$ planes along the $\langle 001\rangle$ directions because of the existence of anti-phase boundaries in these planes. ${ }^{[65]}$ Because of the several operative active slip systems, the $\mathrm{Ni}_{2} \mathrm{TiAl}$ phase can accommodate a finite degree of deformations. Whereas, in the compounds based on $\mathrm{MoSi}_{2}$ type bct structure, such as $\mathrm{CuTi}_{2}$, the only operative slip system at low temperatures is $\{011\}\langle 100\rangle^{[66]}$ and, hence, is and hence are expected to be brittle. Therefore, in the bending experiments, the cracks are likely to propagate through the $(\mathrm{Ag}, \mathrm{Cu}) \mathrm{Ti}_{2}$ phase. The microstructural evidence in Figure 12 shows good agreement with the aforementioned argument; hence, the $(\mathrm{Ag}, \mathrm{Cu}) \mathrm{Ti}_{2}$ phase is primarily responsible for the failure of the brazed joints.

\section{CONCLUSIONS}

Commercially pure grade- $2 \mathrm{Ti}$ was successfully brazed to SS 304L using Silver-ABA alloy at $1203 \mathrm{~K}\left(930{ }^{\circ} \mathrm{C}\right)$, and the following conclusions were drawn from the study.

1. The interfaces of the braze alloy with both the base materials were free from defects such as cracks, pores, and voids.

2. A 5 to $6 \mu \mathrm{m}$ thick Ni-depleted layer was formed on the SS surface due to solid-liquid interaction. The $\mathrm{Ni}$ and $\mathrm{Fe}$ dissolved from SS during brazing precipitated in the form of a discontinuous layer of $(\mathrm{Ni}, \mathrm{Fe})_{2} \mathrm{TiAl}$ adjacent to the SS-braze alloy interface.

3. At the Ti-braze alloy interface, three parallel contiguous layers of intermetallic compounds, viz., CuTi, $\mathrm{AgTi}$, and $(\mathrm{Ag}, \mathrm{Cu}) \mathrm{Ti}_{2}$, formed by the reaction of $\mathrm{Ti}$ and the molten braze alloy. The diffusion path for the reaction at this interface was established.

4. The microstructure of the unreacted braze alloy layer showed formation of nanocrystals of $\mathrm{Ag}-\mathrm{Cu}$ alloy of size ranging between 20 and $30 \mathrm{~nm}$.

5. $\mathrm{Cu}$ and $\mathrm{Ag}$ diffused up to a depth of $40 \mu \mathrm{m}$ into the $\beta$-Ti during brazing, which transformed to fine lamellar eutectoid products of $\alpha$-Ti and $(\mathrm{Cu}, \mathrm{Ag}) \mathrm{Ti}_{2}$, with interlamellar distance of about 500 to $600 \mathrm{~nm}$. The orientation relationship between the two phases was established. The electron diffraction pattern from the $(\mathrm{Cu}, \mathrm{Ag}) \mathrm{Ti}_{2}$ phase suggested it to be internally twinned.

6. Bend tests on thin slices of Ti-SS joints revealed that the crack forms and propagates primarily along the Ti-braze alloy interface through the $(\mathrm{Ag}, \mathrm{Cu}) \mathrm{Ti}_{2}$ phase layer, and the failure of the joints was attributed to the lack of ductility in this intermetallic phase.

\section{ACKNOWLEDGMENTS}

The work is a part of the India-UK collaborative research program JOINT. One of the authors (AAS) is grateful to the UK's Engineering and Physical Sciences Research Council (EPSRC) for the financial support. The authors are also thankful to Mr. P. Mishra, Materials Processing Division, BARC, for providing the Silver-ABA foils, to Mr. S.B. Jawale, Head, Centre for Design and Manufacturing, BARC, Mrs. B.A. Chalke, TIFR, Mumbai, and Professor I. Samajdar, IIT Bombay for their, cooperation and extension of the experimental facilities. The assistance of Mr. P.G. Adiga with the brazing experiments and the helpful discussion with Mr. S. Neogy, Materials Science Division, BARC, on analysis of the results is also gratefully acknowledged.

\section{REFERENCES}

1. A. Shapiro and A. Rabinkin: Weld. J, 2003, vol. 83, pp. 36-43.

2. S. Kundu, M. Ghosh, A. Laik, K. Bhanumurthy, G.B. Kale, and S. Chatterjee: Mater. Sci. Eng. A, 2005, vol. 407, pp. 36-43. 
3. U.K. Mudali, B.M. Ananda Rao, K. Shanmugam, R. Nataraj, and B. Raj: J. Nucl. Mater., 2003, vol. 321, pp. 40-48.

4. P. He, J. Zang, R. Zhou, and X. Li: Mater. Charact., 1999, vol. 43, pp. 287-92.

5. N. Orhan, T.I. Khan, and M. Eroglu: Scripta Mater., 2001, vol. 45 , pp. 441-46.

6. J.G. Lee, S.J. Hong, M. Lee, and C. Rhee: Scripta Mater., 2009, vol. 395 , pp. $145-49$.

7. X. Yue, P. He, J.C. Zhang, and F.Q. Zhu: Mater. Charact, 2008, vol. 59, pp. 1721-27.

8. A. Elrefaey and W. Tillmann: Weld. J., 2008, vol. 87, pp. 113s-18s.

9. J.G. Lee, S.J. Hong, M.K. Lee, and C.K. Rhee: J. Nucl. Mater., 2009, vol. 395, pp. 145-49.

10. P. He, X. Yue, and J.H. Zhang: Mater. Sci. Eng. A, 2008, vol. 486, pp. $171-76$

11. M. Ghosh, S. Chatterjee, and B. Mishra: Mater. Sci. Eng. A, 2003, vol. 363 , pp. $268-74$

12. B. Kurt, N. Orhan, E. Evin, and A. Calik: Mater. Lett., 2007, vol. 61 , pp. $1747-50$

13. V.A. Sidyakin, D.K. Pechenkin, V.M. Arbuzov, and V.S Khaustov: Weld. Int., 2004, vol. 18, pp. 977-98.

14. B. Qin, G.M. Sheng, J.W. Huang, B. Zhou, S.Y. Qiu, and C. Li: Mater. Charact., 2006, vol. 56, pp. 32-38.

15. N. Kahraman, B. Gulenc, and F. Findik: J. Mater. Proc. Technol., 2005, vol. 169, pp. 127-33.

16. A. Nobili, T. Masri, and M.C. Lafont: Proceedings of Reactive Metals in Corrosive Application Conference, Wah Chang, Albany, OR, 1999, pp. 89-98.

17. H. Akbulut, O.T. Inal, and C.A. Zimmerly: J. Mater. Sci., 1999, vol. 34, pp. 1641-52.

18. P. Manikandan, K. Hokamoto, A.A. Deribas, K. Raghukandan, and R. Tomoshige: Mater. Trans., 2006, vol. 47, pp. 1071-84.

19. B. Sabirov, J. Budagov, A. Sissakian, G. Shirkov, Y. Taran, G. Trubnikov, N. Dhanarai, M. Foley, E. Harms, D. Mitchell, S. Nagaitsev, W. Soyars, V. Rybakov, Y. Samarokov, Z. Zhigalov, A. Basti, and F. Bedeschi: 2012, arXiv:1201.3472v1 [physics.insdet].

20. N.A. Dececco and J.N. Parks: Weld. J., 1953, vol. 32, pp. 1071-81.

21. M.M. Schwartz: Brazing, ASM International, Materials Park, $\mathrm{OH}, 2003$.

22. A. Elrefaey and W. Tillmann: Metall. Mater. Trans. A, 2007, vol. 38 A, pp. $2956-62$.

23. A. Elrefaey and W. Tillmann: J. Mater. Sci., 2007, vol. 42, pp. $9553-58$.

24. A. Elrefaey and W. Tillmann: J. Alloys Compd., 2009, vol. 487, pp. 639-45.

25. A. Elrefaey and W. Tillmann: J. Mater. Sci, 2010, vol. 45, pp. $4332-38$.

26. J.G. Lee, J.K. Lee, S.M. Hong, M.K. Lee, and C.K. Rhee: $J$. Mater. Sci, 2010, vol. 45, pp. 6837-40.

27. M.K. Lee, J.G. Lee, Y.H. Choi, D.W. Kim, C.K. Rhee, Y.B. Lee, and S.J. Hong: Mater. Lett., 2010, vol. 64, pp. 1105-08.

28. Y. Flom: Brazing and Soldering 2012: Proc. 5th Int. Brazing and Soldering Conf., ASM International, Las Vegas, NV, 2012, pp. $125-28$.

29. Y. Flom: Brazing and Soldering 2012: Proc. 5th Int. Brazing and Soldering Conf., ASM International, Las Vegas, NV, 2012, pp. 129-33.

30. J.L. Pouchou and F. Pichoir: Microbeam Analysis, San Francisco Press, San Francisco, CA, 1988, pp. 315-18.

31. A.A. Shirzadi, M. Kocak, and E.R. Wallach: Sci. Technol. Weld. Join., 2004, vol. 9, pp. 277-79.

32. O. Kubaschewski: Ternary Alloys: A Comprehensive Compendium of Evaluated Constitutional Data and Phase Diagrams, G. Petzow and G. Effenberg, eds., VCH Verlagsgesellschraft, Weinheim, 1988 , vol. 1 , pp. $557-62$.

33. O. Kubaschewski: Ternary Alloys: A Comprehensive Compendium of Evaluated Constitutional Data and Phase Diagrams, G. Petzow and G. Effenberg, eds., VCH Verlagsgesellschraft, Weinheim, 1988, vol. 1, pp. 596-604.
34. H. Tas, P. Lemaitre, J. Dekeyser, W. Vandermeulen, and F.D. Schutter: Fus. Eng. Design, 1991, vol. 14, pp. 321-28.

35. A. Aiello, M. Azzati, G. Benamati, A. Gessi, B. Long, and G. Scaddozzo: J. Nucl. Mater, 2004, vol. 335, pp. 169-73.

36. O. Kubaschewski: in Ternary Alloys: A Comprehensive Compendium of Evaluated Constitutional Data and Phase Diagrams, G. Petzow and G. Effenberg, eds., VCH Verlagsgesellschraft, Weinheim, 1988, vol. 2, pp. 55-59.

37. O. Kubaschewski: in Landolt-Bornstein New Series, Springer, New York, NY, 2005, vol. IV/11C3, pp. 63-74.

38. B.P. Budberg: in Ternary Alloys: A Comprehensive Compendium of Evaluated Constitutional Data and Phase Diagrams, G. Petzow and G. Effenberg, eds., VCH Verlagsgesellschraft, Weinheim, 1988, vol. 8, pp. $7-21$.

39. J.C. Schuster, Z. Pan, S. Liu, F. Weitzer, and Y. Du: Intermetallics, 2007, vol. 15, pp. 1257-67.

40. V. Raghavan: J. Phase Equilib. Differ., 2009, vol. 30, pp. 77-78.

41. G. Ghosh: in Ternary Alloys: A Comprehensive Compendium of Evaluated Constitutional Data and Phase Diagrams, G. Petzow and G. Effenberg, eds., VCH Verlagsgesellschraft, Weinheim, 1988, vol. 5, pp. 456-69.

42. G. Ghosh: in Landolt-Bornstein New Series, Springer, New York, NY, 2005, vol. IV (11A2), pp. 426-52.

43. R. Kainuma, K. Urushiyama, K. Ishikawa, C.C. Jia, I. Ohnuma, and K. Ishida: Mater. Sci. Eng., 1997, vols. 239-240, pp. 235-44.

44. X. Yan, A. Grytsiv, P. Rogl, V. Pomjakushin, and H. Schmidt: $J$. Phase Equilib. Differ., 2008, vol. 29, pp. 414-28.

45. C.C. Liu, C.L. Ou, and R.K. Shiue: J. Mater. Sci., 2002, vol. 37, pp. $2225-35$.

46. M.Singleton and P. Nash: in: Binary Alloy Phase Diagrams, 2nd ed., T.B. Massalski, H. Okamoto, P.R. Subramanian, and L. Kacprzak, eds., ASM International, Materials Park, OH, 1990, pp. 64-66.

47. J. Swartzendruber: in Binary Alloy Phase Diagrams, 2nd ed., T.B. Massalski, H. Okamoto, P.R. Subramanian, and L. Kacprzak, eds., ASM International, Materials Park, OH, 1990, pp. 35-37.

48. R.A. Swalin and V.G. Leak: Acta Metall., 1965, vol. 13, pp. 47178.

49. J.S. Kirkaldy and L.S. Brown: Can. Metall. Q, 1963, vol. 2, pp. 89-111.

50. K.S. Kirkaldy and D.J. Young: Diffusion in the Condensed State, Institute of Metals, London, 1987, pp. 382-90.

51. J.E. Morral: Metall. Mater. Trans. A, 2012, vol. 43A, pp. 3462-70.

52. R.K. Shiue, S.K. Wu, and C.H. Chan: J. Alloys Compd., 2004, vol. 372 , pp. $148-57$.

53. N.A. Tiner: Weld. J., 1955, vol. 34, pp. 846-85.

54. E. Ganjeh, H. Sarkhosh, H. Khorsand, H. Sabet, E.H. Dehkordi, and M. Ghaffari: Mater. Des., 2012, vol. 39, pp. 33-41.

55. O. Caloni, A. Ferrari, and P. Strocchi: Electrochim. Metall., 1969, vol. 4 , pp. $45-48$.

56. J. Askill: Phys. Status Solidi, 1971, vol. 43, pp. K1-K2.

57. H. Araki, T. Yamane, Y. Minamino, S. Saji, Y. Hana, and S. Jung: Metall. Mater. Trans. A, 1994, vol. 25, pp. 874-76.

58. J.L. Murray: in Binary Alloy Phase Diagrams, 2nd ed., T.B. Massalski, H. Okamoto, P.R. Subramanian, and L. Kacprzak, eds., ASM International, Materials Park, OH, 1990, pp. 225-26.

59. H. Okamoto: J. Phase Equilib., 2002, vol. 26, pp. 549-50.

60. R.I. Jaffee: Prog. Met. Phys., 1958, vol. 7, pp. 65-163.

61. F.C. Holden, A.A. Watts, H.R. Ogden, and R.I. Jaffee: Trans. AIME, 1955, vol. 203, pp. 117-25.

62. T.A. Bhaskaran, R.V. Krishnan, and S. Ranganathan: Metall. Mater. Trans. A, 1995, vol. 26A, pp. 1367-77.

63. J.C. Williams, R. Taggart, and D.H. Polonis: Metall. Trans. A, 1971, vol. 2A, pp. 1139-48.

64. P. Mukhopadhyay, S.K. Menon, S. Banerjee, and R. Krishnan: Metall. Trans. A, 1979, vol. 10A, pp. 1071-84.

65. M. Yamaguchi and Y. Umakoshi: Prog. Mater. Sci., 1009, vol. 34, pp. $1-148$.

66. S.A. Maloy, A.H. Heuer, J.J. Lewandowski, and T.E. Mitchell: Acta Metall. Mater., 1992, vol. 40, pp. 3159-65. 